\section{Pacific Northwest}

National Laboratory

Operated by Battelle for the

U.S. Department of Energy

\section{Summary of Hanford Site Groundwater Monitoring for Fiscal Year 2003}

\section{Editors}

\author{
M. J. Hartman \\ L. F. Morasch \\ W. D. Webber
}

March 2004

Prepared for the U.S. Department of Energy under Contract DE-AC06-76RL01830 


\section{DISCLAIMER}

This report was prepared as an account of work sponsored by an agency of the United States Government. Reference herein to any specific commercial product, process, or service by trade name, trademark, manufacturer, or otherwise does not necessarily constitute or imply its endorsement, recommendation, or favoring by the United States Government or any agency thereof, or Battelle Memorial Institute.

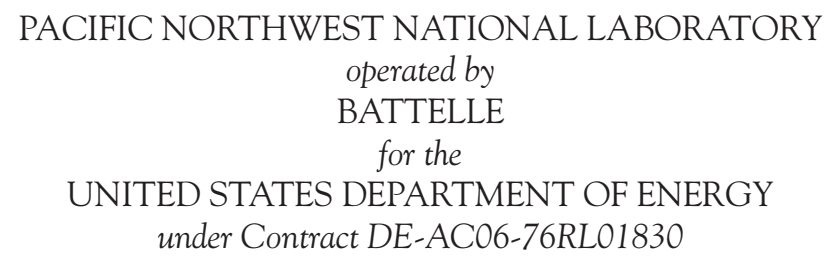

Printed in the United States of America

Available to DOE and DOE contractors from the Office of Scientific and Technical Information, P.O. Box 62, Oak Ridge, TN 37831; prices available from (615) 576-8401.

Available to the public from the National Technical Information Service, U.S. Department of Commerce, 5285 Port Royal Rd., Springfield, VA 22161 


\title{
Summary of Hanford Site Groundwater Monitoring for Fiscal Year 2003
}

\section{Editors}

\author{
M. J. Hartman \\ L. F. Morasch \\ W. D. Webber
}

March 2004

Prepared for the U.S. Department of Energy by Pacific Northwest National Laboratory under Contract DE-AC06-76RL01830, with contributions from CH2M HILL Hanford, Inc.; CH2M HILL Hanford Group, Inc.; Fluor Hanford, Inc.; Lawrence Berkley National Laboratory; S.M. Stoller Corporation; Stanford University; and Utah State University

Pacific Northwest National Laboratory Richland, Washington 99352 


\section{Contents}

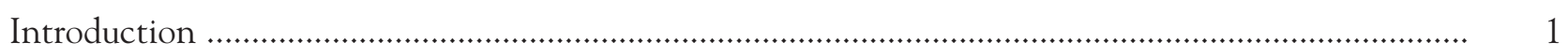

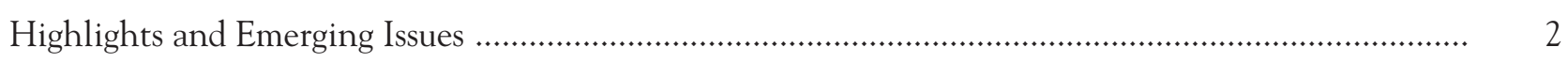

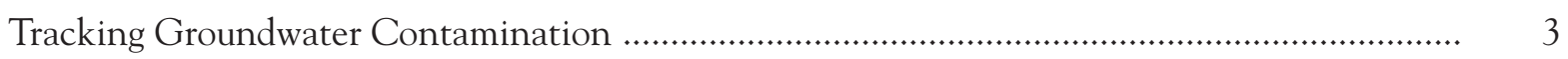

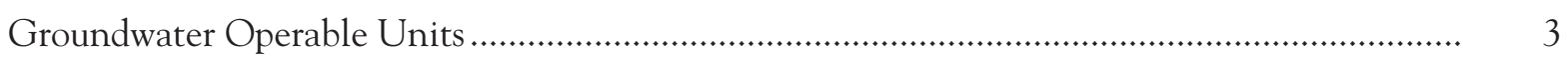

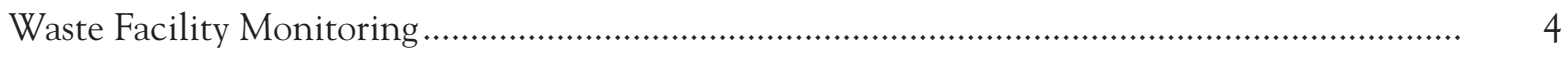

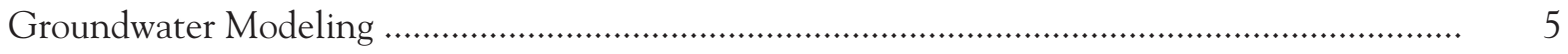

Vadose Zone ....................................................................................................................

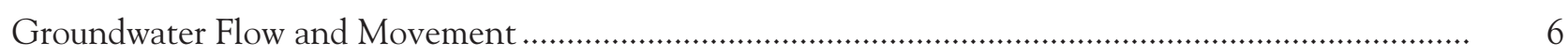

Groundwater Monitoring and Remediation ............................................................................. 7

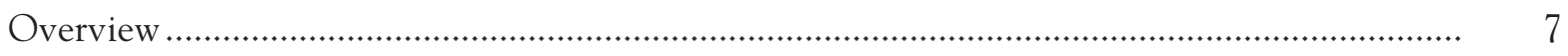

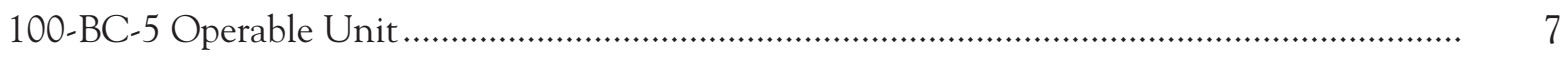

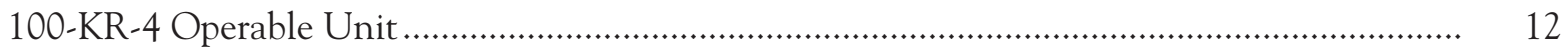

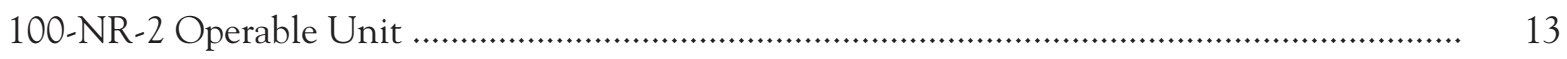

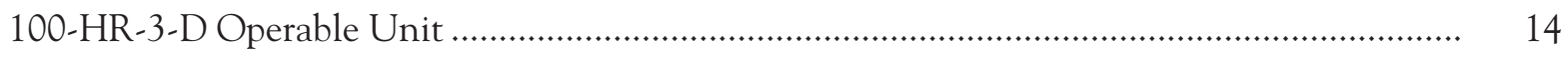

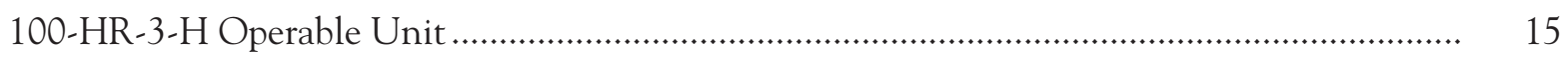

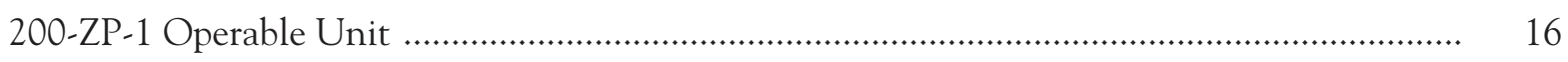

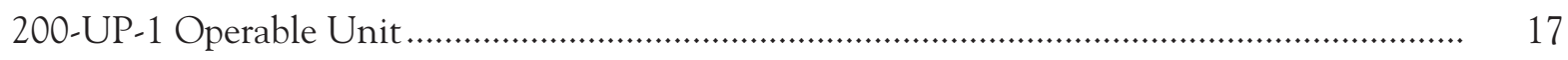

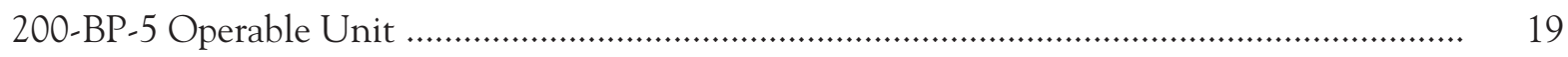

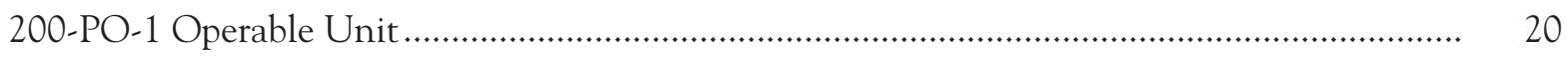

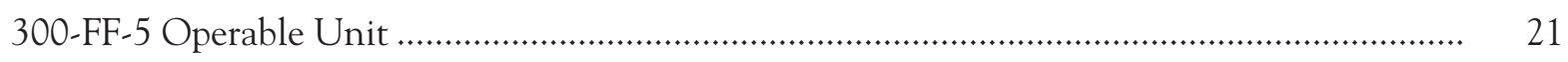

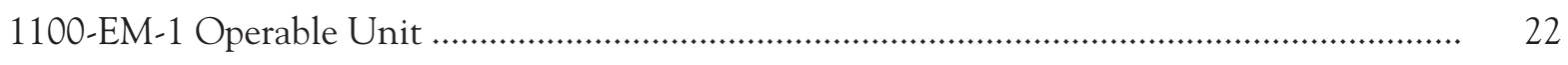

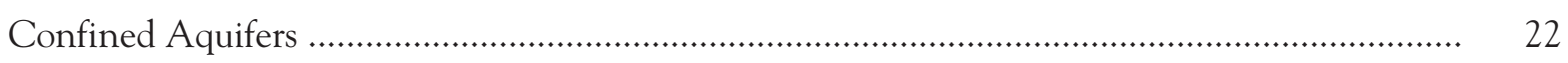

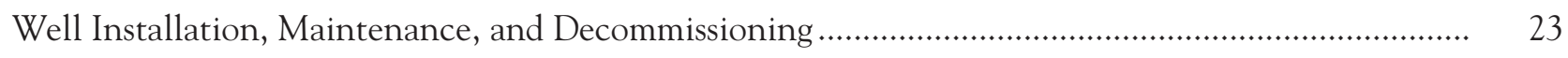

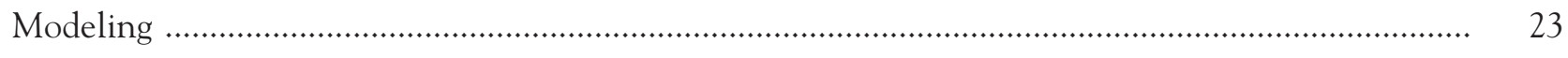

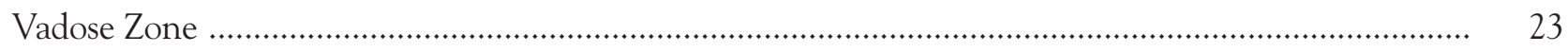




\section{Introduction}

The Hanford Site, a facility in the U.S. Department of Energy (DOE) nuclear weapons complex, encompasses $~ 1,517$ square kilometers northwest of the city of Richland along the Columbia River in southeast Washington State. The federal government acquired the site in 1943, and until the 1980s it was dedicated primarily to the production of plutonium for national defense and the management of resulting waste. In 1995, all unrestricted discharge of radioactive liquid waste to the ground was discontinued. Today, DOE's mission on the Hanford Site is to restore the Columbia River corridor and transition the central portion of the site toward its long-term waste management role.

DOE has monitored groundwater on the Hanford Site since the 1940s to help determine what chemical and radiological contaminants have made their way into the groundwater. As regulatory requirements for monitoring increased in the 1980s, there began to be some overlap between various programs. DOE established the Groundwater Performance Assessment Project (groundwater project) in 1996 to ensure protection of the public and the environment while improving the efficiency of monitoring activities. The groundwater

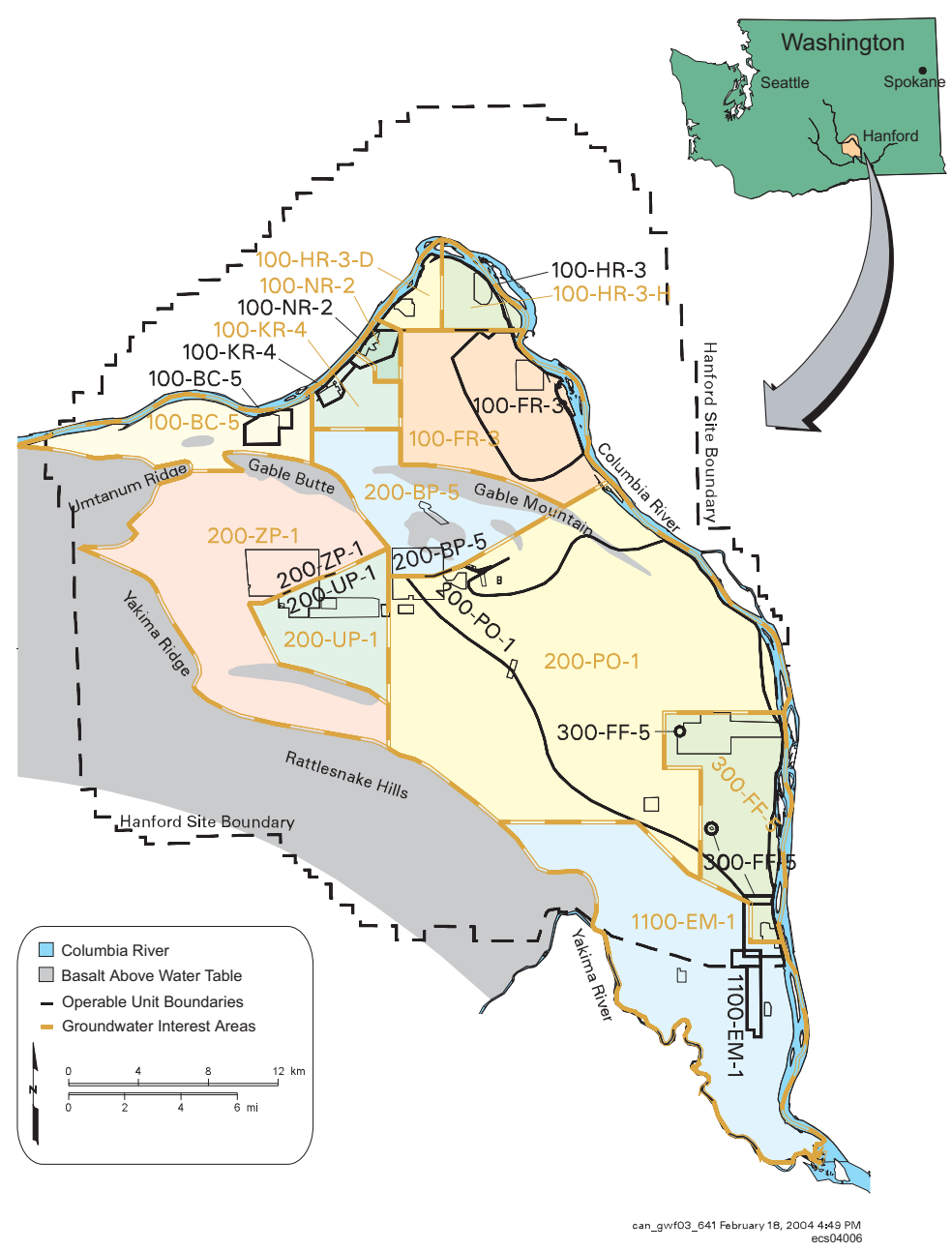

Hanford Site groundwater monitoring is organized by areas of interest, which are informally named after the groundwater operable units.
Groundwater is the water that fills the pores or cracks between grains in a layer of sediment or rock. Groundwater monitoring helps determine what contamination exists beneath the Hanford Site. This information will help regulators and DOE make cleanup decisions. 
This report is written to meet the requirements in the CERCLA, RCRA, Atomic Energy Act of 1954, and Washington Administrative Code.

The Groundwater Project sampled $\sim 710$ wells during fiscal year 2003.

Iodine-129, nitrate, and tritium are the most widespread contaminants. project is designed to support all groundwater monitoring needs at the site, eliminate redundant sampling and analysis, and establish a cost-effective hierarchy for groundwater monitoring activities.

Contamination may reach the Columbia River by moving down through the vadose zone, into the groundwater, and then into the river. The analysis of groundwater samples helps determine the potential effects that contaminants could have on human health and the environment. DOE works with the regulators, such as the U.S. Environmental Protection Agency (EPA) and the Washington State Department of Ecology (Ecology), to make cleanup decisions based on sound technical information and the technical capabilities available.

\section{Highlights and Emerging Issues}

DOE's major accomplishments related to groundwater monitoring in fiscal year 2003, and emerging issues of potential concern, are outlined below.

\section{Groundwater Monitoring Capabilities}

Groundwater Sampling - Workers sampled 710 monitoring wells and 79 shoreline aquifer tubes to determine the distribution and movement of contaminants. Many of the wells were sampled multiple times during the year.

Sample Analysis - One thousand seven hundred and twenty-three samples of Hanford groundwater were analyzed for chromium, 1,181 for nitrate, and 908 for tritium. Other constituents frequently analyzed include carbon tetrachloride, technetium-99, and uranium, which were analyzed in $\sim 600$ samples.

Adequacy of Monitoring Networks - Water levels in the 200 Areas continued to drop, causing more monitoring wells to go dry in fiscal year 2003. Changes in groundwater flow or chemistry also affect the effectiveness of monitoring networks.

New Wells - DOE, Ecology, and EPA agreed to revise a Tri-Party Agreement milestone to allow prioritization of drilling for Comprehensive Environmental Response, Compensation, and Liability Act (CERCLA) and Atomic Energy Act of 1954 (AEA) wells along with Resource

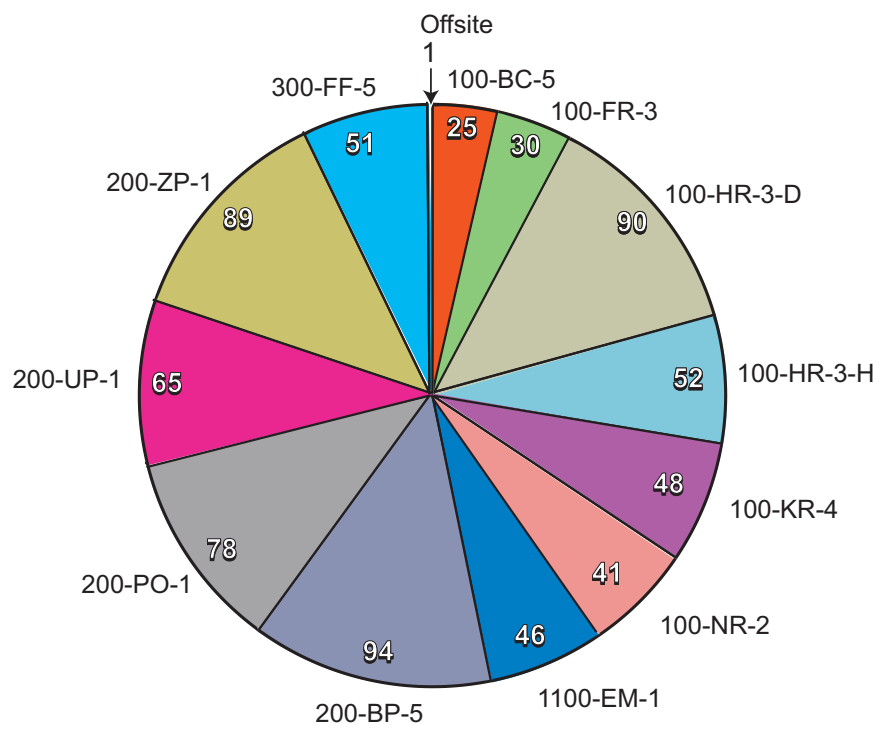

ecs04001

This chart shows the number of wells sampled in each groundwater interest area in fiscal year 2003. 
Conservation and Recovery Act (RCRA) wells. During calendar year 2003, drillers completed seven new RCRA monitoring wells, nine wells for CERCLA, and two wells for research on chromate bioremediation.

River Shoreline Monitoring - DOE monitors aquifer sampling tubes near the Columbia River to track contaminants entering the river. In fiscal year 2004, DOE will install additional tubes in the 100-B/C, 100-K, 100-D, 100-H, 100-F, and 300 Areas.

\section{Tracking Groundwater Contamination}

Site-Wide Tritium Plume - Monitoring indicated that the Hanford Site's largest contaminant plume is gradually decreasing in size and is not affecting Richland's watersupply wells. The plume is expected to continue to shrink.

Tritium in 100-K Area - Tritium concentrations increased in two wells near the KE Basin and one well near the KW Basin in fiscal year 2003. However, supporting data indicate that the rise was not due to new leakage from the basins. DOE continued to investigate tritium in the vicinity of a burial ground in the 100-K Area. Results indicated the presence of a vadose zone source along with an underlying plume in the groundwater.

Chromium in 100-D Area - Chromium levels continued to increase sharply in the central 100-D Area, between the influence of the two interim remedial action systems where it could migrate to the Columbia River. DOE and the regulators will expand remedial measures to address this change.

Carbon Tetrachloride Plume - This plume beneath the 200 West Area is gradually spreading at the $5-\mathrm{mg} / \mathrm{L}$ contour, but the high-concentration portion of the plume is contained. In some locations, carbon tetrachloride concentrations are higher deep in the aquifer than near the water table. This issue will continue to be studied in fiscal year 2004 .

\section{Groundwater Operable Units}

Interim Remedial Actions - Remediation systems continued to limit the spread of groundwater contamination in the 100 and 200 Areas. Since their inception, remedial

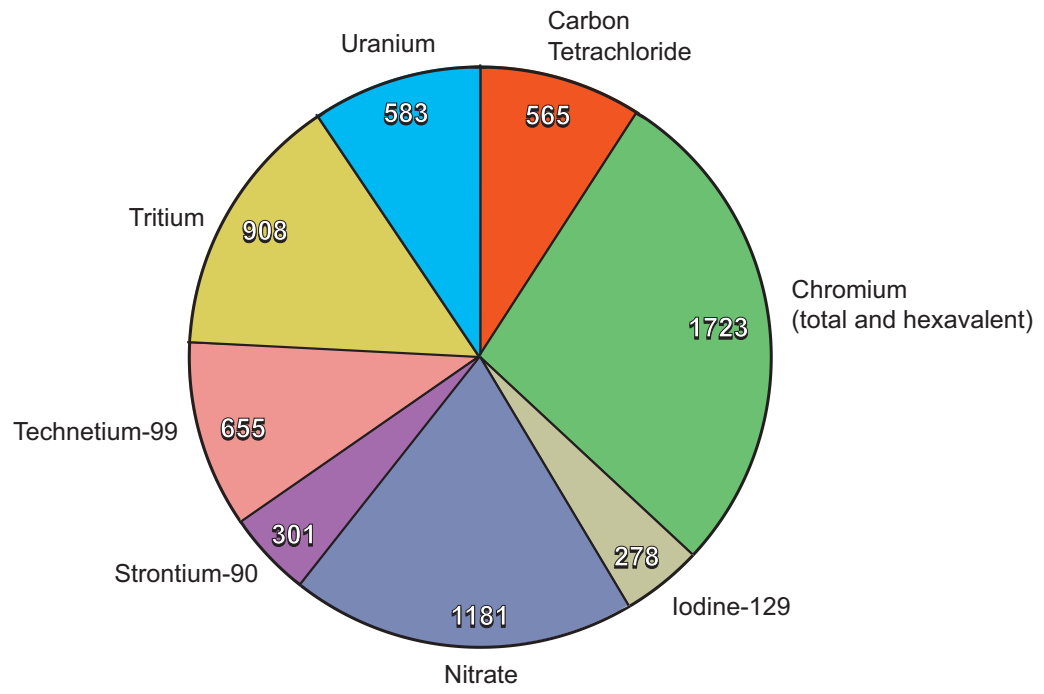

ecs04002

The groundwater project requests specific laboratory analyses based on the well's location, historical contaminant trends, and regulatory requirements. This graph shows the number of analyses for the most common constituents during fiscal year 2003.
Monitoring wells

provide samples of

groundwater from

across the Hanford

Site. DOE uses

information gained

from these samples

to evaluate risk to

human health and

the environment. 


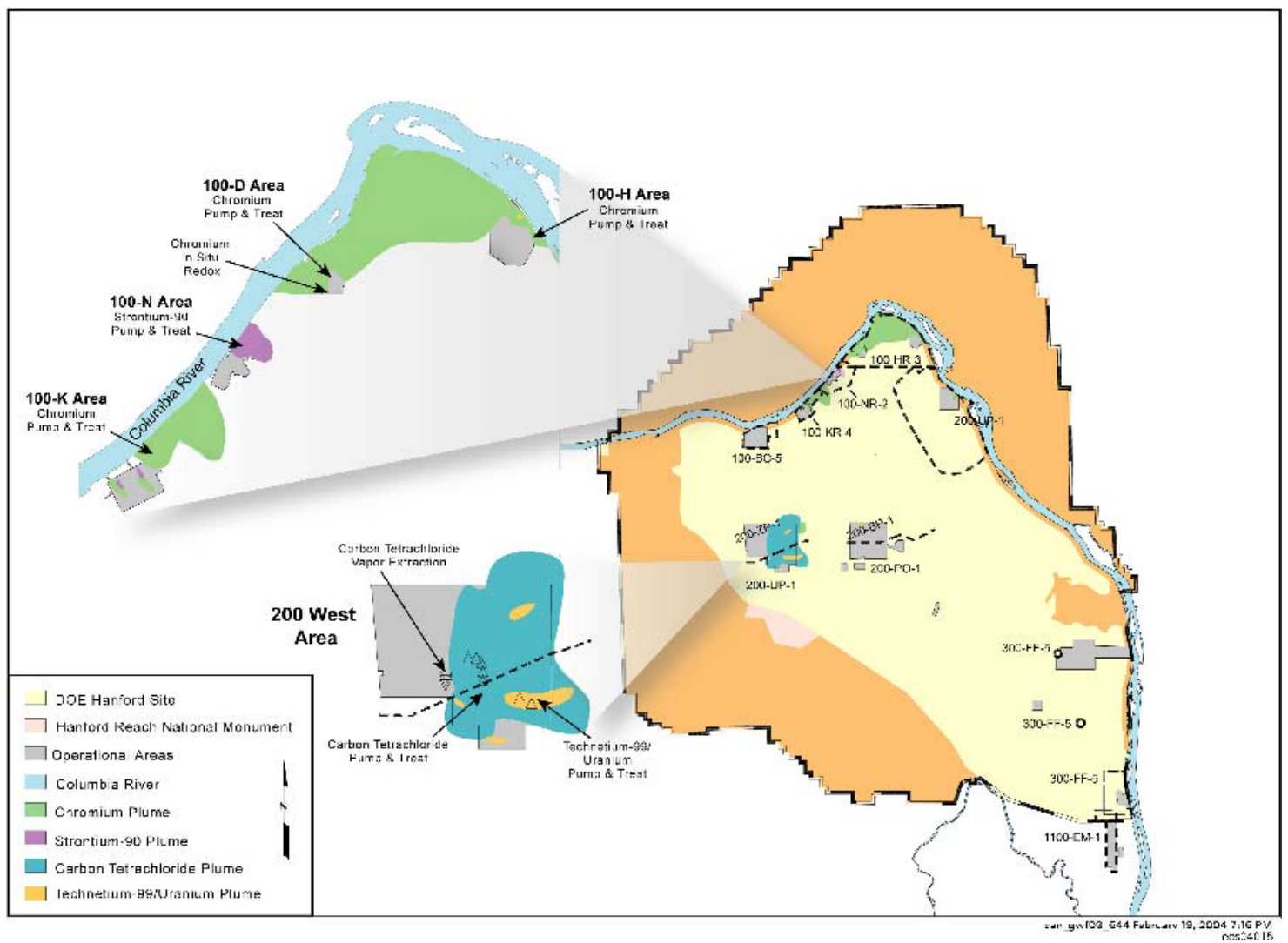

DOE operates five pump-and-treat systems, one in situ remediation system, and one soil-gas extraction system to remove contaminants and limit their movement in groundwater and the vadose zone.

Groundwater can

be pumped from the subsurface and

treated to remove

contaminants. This

process, referred to

as a pump-and-

treat system, is

being used at

Hanford to remove

carbon

tetrachloride,

chromium,

strontium-90,

technetium-99, and

uranium. measures have treated over 7 billion liters of groundwater to remove carbon tetrachloride, chromium, strontium-90, technetium-99, and uranium. DOE is evaluating alternative technologies for strontium-90 remediation.

Monitored Natural Attenuation - Average trichloroethene concentrations in compliance wells in the 1100-EM-1 Operable Unit remained below the drinking water standard for the third year in a row. This contaminant has been attenuating naturally. Average trichloroethene concentrations also remained below the drinking water standard in the 300-FF-5 Operable Unit, but uranium is slow to attenuate.

CERCLA Sampling and Analysis Plans - DOE released new plans for long-term groundwater monitoring in the 100-BC-5, 100-FR-3, and 200-BP-5 Operable Units in fiscal year 2003. A sampling and analysis plan for the 200-PO-1 Operable Unit was drafted in fiscal year 2003 and released in fiscal year 2004.

Working Toward Final Remediation Decisions - Final decisions for groundwater remediation have been made only for the 1100-EM-1 Operable Unit. DOE and the regulators are beginning the process to determine what information is needed to make final decisions for the 100-BC-5, 100-FR-3, 200-BP-5, 200-UP-1, 200-ZP-1, 200-PO-1, and 300-FF-5 Operable Units.

\section{Waste Facility Monitoring}

Resource Conservation and Recovery Act (RCRA) - The groundwater project continued to monitor 24 RCRA sites in fiscal year 2003. RCRA monitoring provided no evidence of new contamination from sites in detection programs. Seven sites continued to be monitored under assessment programs, and two under final status corrective action. 


\begin{tabular}{|c|c|c|}
\hline \multicolumn{3}{|c|}{ Groundwater Remediation } \\
\hline Remedial Action Site & Startup Date & Progress From Startup to September 2003 \\
\hline 100-K Area 100-KR-4 Pump-and-Treat & 1997 & $\begin{array}{l}\text { Decreases chromium to river; } 213 \text { kilograms chromium } \\
\text { removed. }\end{array}$ \\
\hline 100-N Area 100-NR-2 Pump-and-Treat & 1995 & $\begin{array}{l}\text { Diverts strontium-90 from river; } 1.45 \text { curies strontium-90 } \\
\text { removed; } 12 \text { curies decayed naturally. }\end{array}$ \\
\hline 100-D Area 100-HR-3 Pump-and-Treat & 1997 & $\begin{array}{l}\text { Decreases chromium to river; } 161 \text { kilograms chromium } \\
\text { removed. }\end{array}$ \\
\hline 100-D Area 100-HR-3 In Situ Redox & 1999 & $\begin{array}{l}\text { Decreases chromium concentration downgradient of } \\
\text { barrier. }\end{array}$ \\
\hline 100-H Area 100-HR-3 Pump-and-Treat & 1997 & $\begin{array}{l}\text { Decreases chromium to river; } 34 \text { kilograms chromium } \\
\text { removed. }\end{array}$ \\
\hline 200 West Area 200-ZP-1 Pump-and-Treat & 1994 & $\begin{array}{l}\text { Prevents high-concentration portion of carbon tetrachlo- } \\
\text { ride plume from spreading; } 7,668 \text { kilograms removed. }\end{array}$ \\
\hline 200 West Area Soil-Vapor Extraction & 1992 & $\begin{array}{l}\text { Prevents carbon tetrachloride movement to ground- } \\
\text { water; } 78,100 \text { kilograms removed from vadose zone. }\end{array}$ \\
\hline 200 West Area 200-UP-1 Pump-and-Treat & 1994 & $\begin{array}{l}\text { Decreases migration of contaminants; } 102 \text { grams } \\
\text { technetium-99 ( } 1.7 \text { curies) and } 180 \text { kilograms uranium } \\
\text { removed. }\end{array}$ \\
\hline 300-FF-5 Natural Attenuation & $\begin{array}{l}\text { Not } \\
\text { applicable }\end{array}$ & $\begin{array}{l}\text { Average trichloroethene concentrations below target } \\
\text { level; uranium concentrations above target level. }\end{array}$ \\
\hline $1100-E M-1$ Natural Attenuation & $\begin{array}{c}\text { Not } \\
\text { applicable }\end{array}$ & $\begin{array}{l}\text { Average trichloroethene concentrations below } 5 \mu g / L \\
\text { since } 2001 \text {. }\end{array}$ \\
\hline
\end{tabular}

Evaluation of Alternative RCRA Statistical Methods - The groundwater project completed data collection for alternative statistical methods at the 216-B-3 pond and 316-5 process trenches. The project will release a report on the results of applying these methods in fiscal year 2004.

Other Regulated Units - The groundwater project continued to monitor four waste disposal sites regulated under state requirements other than RCRA. Monitoring results at the following regulated units remained within permit limits: 400 Area process ponds, StateApproved Land Disposal Site, and 200 Area Treated Effluent Disposal Facility. At the Solid Waste Landfill, specific conductance, $\mathrm{pH}$, chloride, and sulfate exceeded their background threshold levels in one or more samples.

Environmental Restoration Disposal Facility-Concentrations of some constituents of concern were elevated but reflect migration of contaminant plumes from sources in the 200 West Area.

\section{Groundwater Modeling}

Site-Wide Groundwater Model - In fiscal year 2003, development focused on calibration based on an alternative conceptual model.

System Assessment Capability - This integrated system of computer models and databases simulates the movement of contaminants from waste sites through the vadose zone and groundwater. In fiscal year 2003, the model was updated; an atmospheric transport module was added and newer versions of groundwater flow and transport modules were incorporated into the system.

\section{Vadose Zone}

Tank Farm Characterization - In fiscal years 2002 and 2003, DOE drilled boreholes at the T and TX-TY Tank Farms to characterize subsurface contamination near former leak
Hanford
groundwater flows
into the Columbia
River, which is a
major drinking
water source.
Therefore, DOE is
focusing their
remediation efforts
on protecting the
Columbia River. 
sites. Results for TX Tank Farm indicated that the magnitude of contamination is not as great as that found in boreholes at other tank farms. Results for T Tank Farm will be available in 2004.

Tank Farm Monitoring - DOE uses geophysical methods to monitor potential movement of contamination beneath single-shell tank farms. During fiscal year 2003, DOE monitored selected boreholes within each of the 12 single-shell tank farms. In general, the contaminated area appeared to be stable over time.

Carbon Tetrachloride Characterization - Soil vapor near the Plutonium Finishing Plant (200 West Area) was sampled to locate carbon tetrachloride sites with the potential to affect groundwater in the future. Results suggest that there are no active sources of contamination in the upper vadose zone at the locations sampled.

Wells that were formerly sampled for the groundwater project have gone dry as the water table declined. Most of the wells are in the 200 West Area.

\begin{tabular}{|c|c|c|c|c|}
\hline Fiscal Year & 200 West & $\underline{200 \text { East }}$ & Other Areas & Tota \\
\hline 1998 & 2 & 1 & 2 & 5 \\
\hline 1999 & 9 & 0 & 1 & 10 \\
\hline 2000 & 12 & 2 & 2 & 16 \\
\hline 2001 & 7 & 0 & 1 & 8 \\
\hline 2002 & 10 & 2 & 1 & 13 \\
\hline 2003 & 6 & 2 & 3 & 11 \\
\hline Total & 46 & 7 & 10 & 63 \\
\hline
\end{tabular}

\section{Groundwater Flow and Movement}

\section{A groundwater} monitoring network strategically located across the Hanford Site helps determine changes in the direction of groundwater flow as the site returns to pre-Hanford conditions.
Groundwater in the unconfined aquifer generally flows from west to east across the Hanford Site to discharge areas along the Columbia River. The direction of groundwater flow is inferred from water-table elevations, barriers to flow (e.g., basalt or mud units at the water table), and the distribution of contaminants.

General directions of groundwater flow are illustrated on the map (page xv) for March 2003. Beneath the reactor areas, groundwater flows generally toward the Columbia River. Farther inland, north of Gable Mountain, flow is toward the northeast and east. Groundwater flows eastward beneath the 200 Areas and then flows to the southeast or north through the gap between Gable Butte and Gable Mountain. Groundwater converges on the 300 Area from the northwest, west, and southwest and discharges into the Columbia River to the east. Groundwater in the Richland North Area flows generally eastward to the Columbia River.

The natural pattern of groundwater flow was altered during the Hanford Site's operating years by the formation of mounds in the water table. The mounds were created by the discharge of large volumes of wastewater to the ground and were present in each reactor area and beneath the 200 Areas. Since effluent disposal decreased significantly in the 1990s, these mounds are disappearing.

East of the 200 East Area, a fine-grained confining unit creates a barrier to movement in the surrounding unconfined aquifer. Beneath this confining unit, the uppermost aquifer is a permeable unit in the Ringold Formation. Groundwater flow in this confined aquifer still is influenced by a recharge mound. 
Groundwater in the upper basalt-confined aquifer generally flows from west to east across the Hanford Site, up through the unconfined aquifer, and into the Columbia River. Vertical gradients between the basalt-confined aquifer and the unconfined aquifer are upward on most of the Hanford Site. Therefore, there is little potential for contaminants to migrate from the unconfined aquifer into the basalt-confined aquifer, where it could move offsite. Downward gradients are measured beneath the west portion of the Hanford Site and north and east of the Columbia River.

\section{Groundwater Monitoring and Remediation}

This section summarizes results of Hanford Site groundwater monitoring for various requirements, including RCRA and CERCLA. Progress on groundwater remediation also is summarized.

\section{Overview}

DOE has developed a plan to accelerate cleanup of Hanford's groundwater, which will return it to its beneficial use where practicable or will at least prevent further degradation. Specific results that can be expected using the accelerated plan include the following: (a) remediate high-risk waste sites, (b) shrink the contaminated area, (c) reduce recharge, (d) remediate groundwater, and (e) monitor groundwater. The maps on the following pages show the distribution of nine principal groundwater

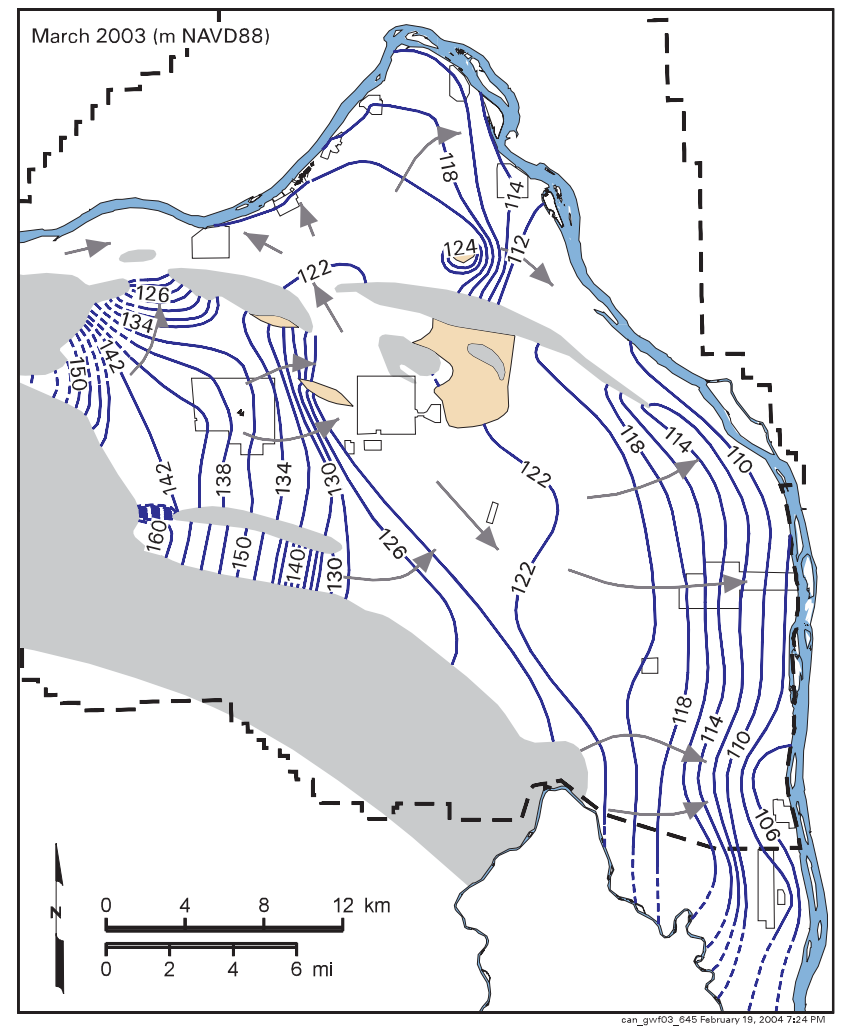

This map shows the water table and inferred flow directions in March 2003. Shaded areas show where the unconfined aquifer is absent. contaminant plumes.

The tritium and iodine-129 plumes have the largest areas with concentrations exceeding drinking water standards. The dominant plumes had sources in the 200 East Area and extend toward the east and southeast. Technetium-99 exceeds standards in smaller plumes, one of which has moved northward from the 200 East Area. Uranium is less mobile than tritium, iodine-129, or technetium-99; small plumes are found in the 100-H, 200 East, 200 West, and 300 Areas. Strontium-90 is not very mobile in groundwater, but it exceeds standards in each of the 100 Areas except 100-D. Other radionuclides including cesium-137, cobalt-60, and plutonium are even less mobile in the subsurface and rarely exceed drinking water standards in Hanford Site groundwater.

Nitrate is a widespread contaminant in Hanford Site groundwater, with plumes originating from the 100 and 200 Areas and from offsite industry and agriculture. Carbon tetrachloride forms a large plume beneath the 200 West Area, the most widespread organic contaminant on the Hanford Site. Other organic contaminants include chloroform and trichloroethene. Chromium contamination underlies the 100-K, 100-D, and 100-H Areas. Local plumes of chromium contamination also are present in the 200 Areas.

Table S-1 lists the maximum concentration of chemical and radioactive constituents in each groundwater operable unit. The following text discusses groundwater contamination, monitoring, and remediation in each of the 11 groundwater operable units and in the confined aquifers.

\section{0-BC-5 Operable Unit}

This operable unit includes the groundwater beneath the 100-B/C Area, located in the northwest Hanford Site. Most of the groundwater contamination is found in the north portion of the area, beneath former waste trenches and retention basins. Tritium and 


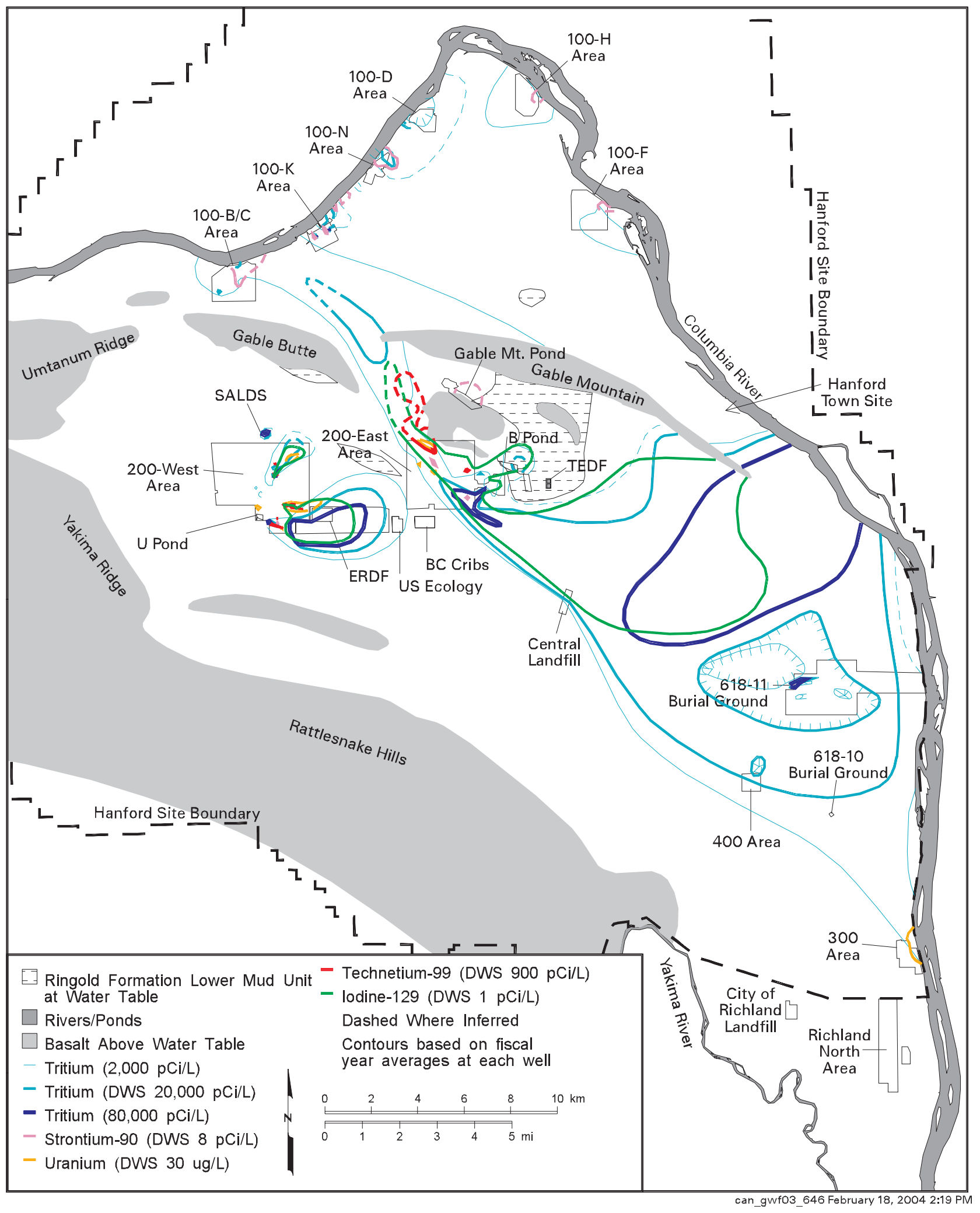

This map shows the distribution of major radionuclides in groundwater at concentrations above drinking water standards during fiscal year 2003. 


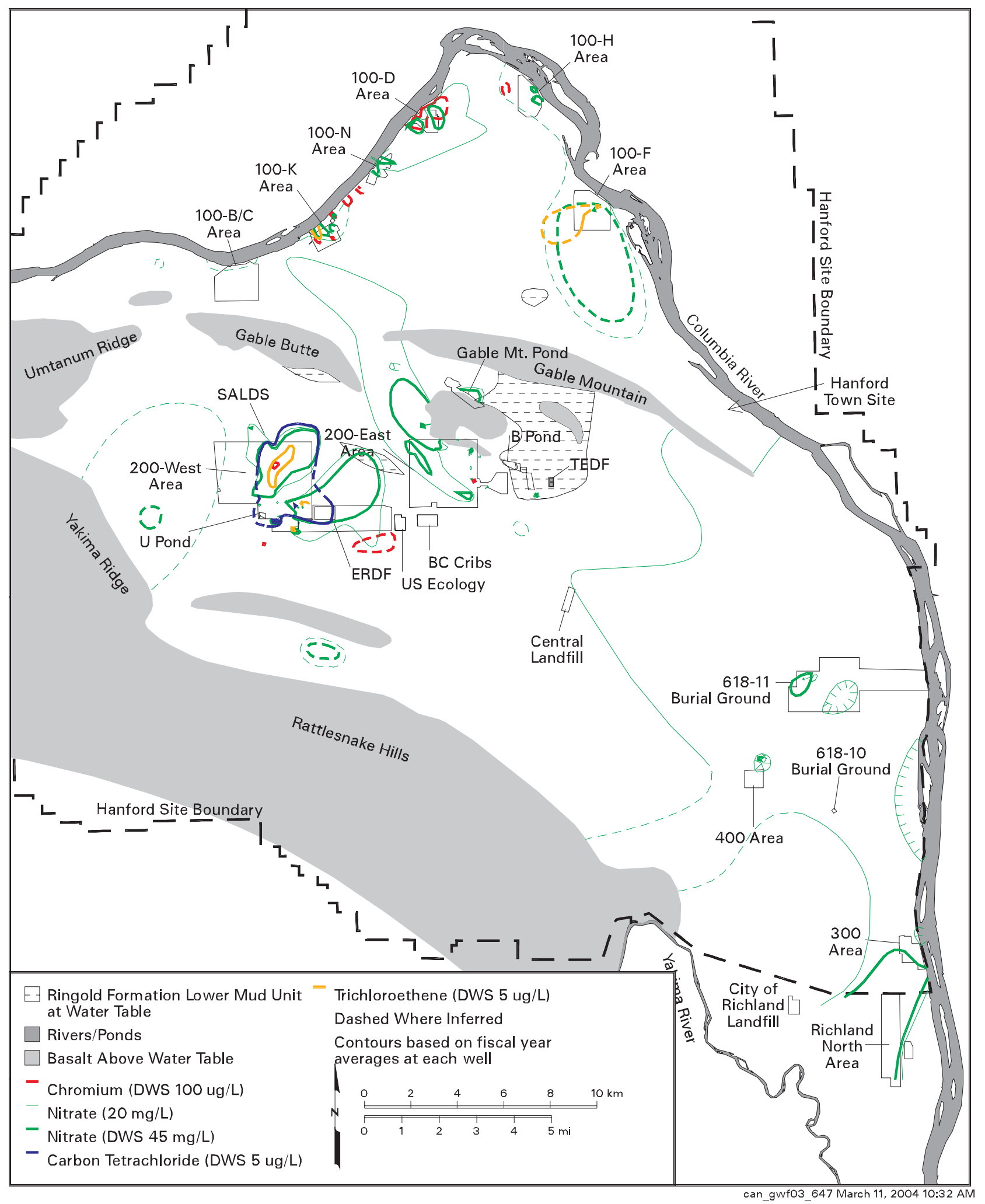

This map shows the distribution of major hazardous chemicals in groundwater at concentrations above drinking water standards during fiscal year 2003. 


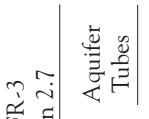

究

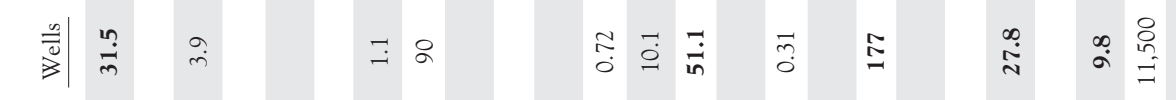

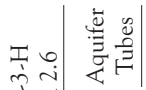

子

辛

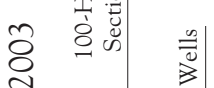

$\stackrel{+}{2}$

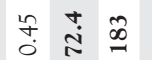

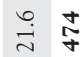

루

๘

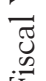

곤

ลิ

$\Xi$ 差

节

in

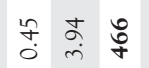

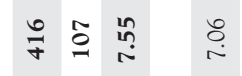

$\begin{array}{ll}8 & \infty \\ \stackrel{2}{*} & \infty \\ \sim & m\end{array}$

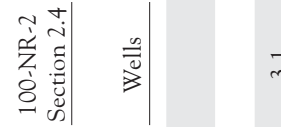

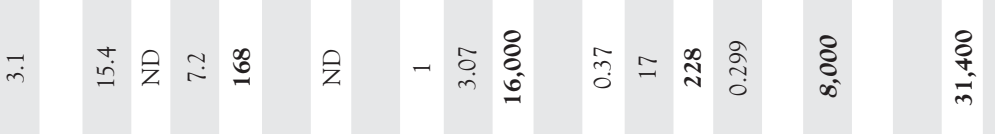

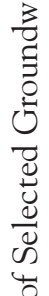

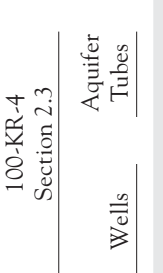

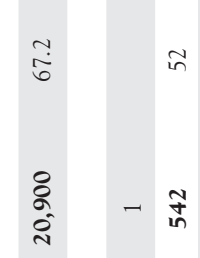

$\stackrel{\circ}{i}$

z

$\frac{1}{2}$

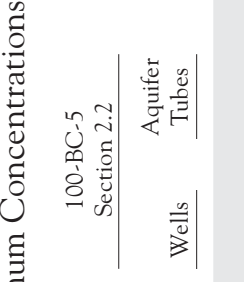

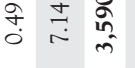

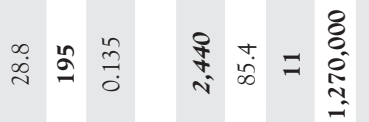

$\infty$

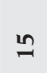

ì

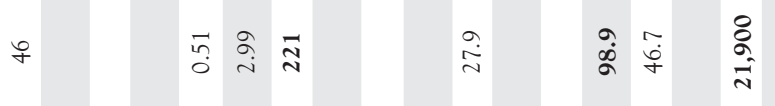

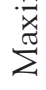

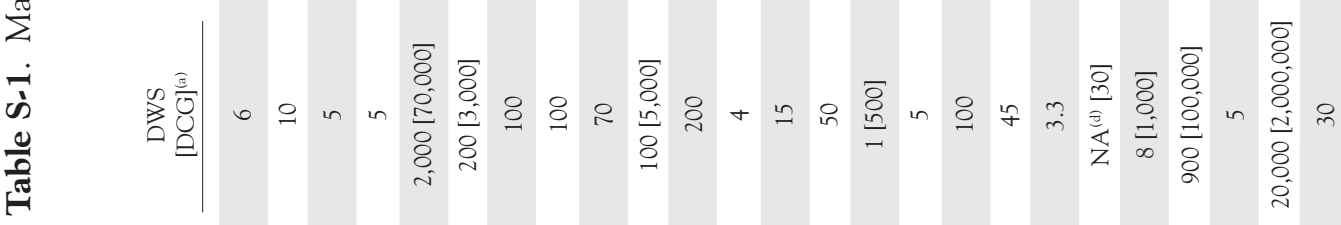

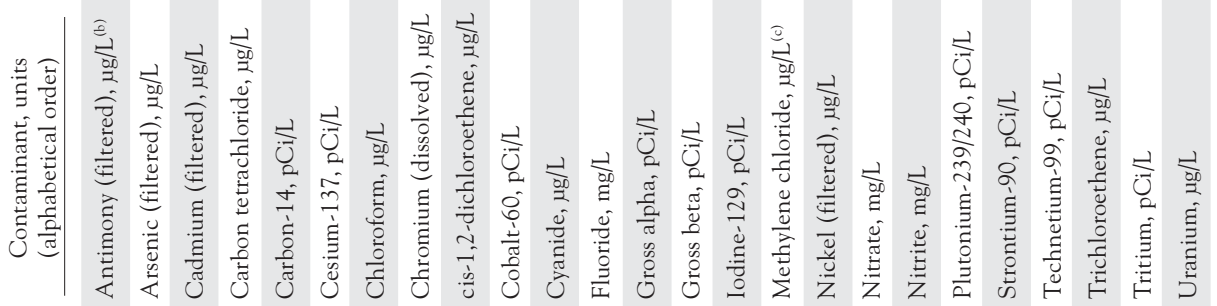




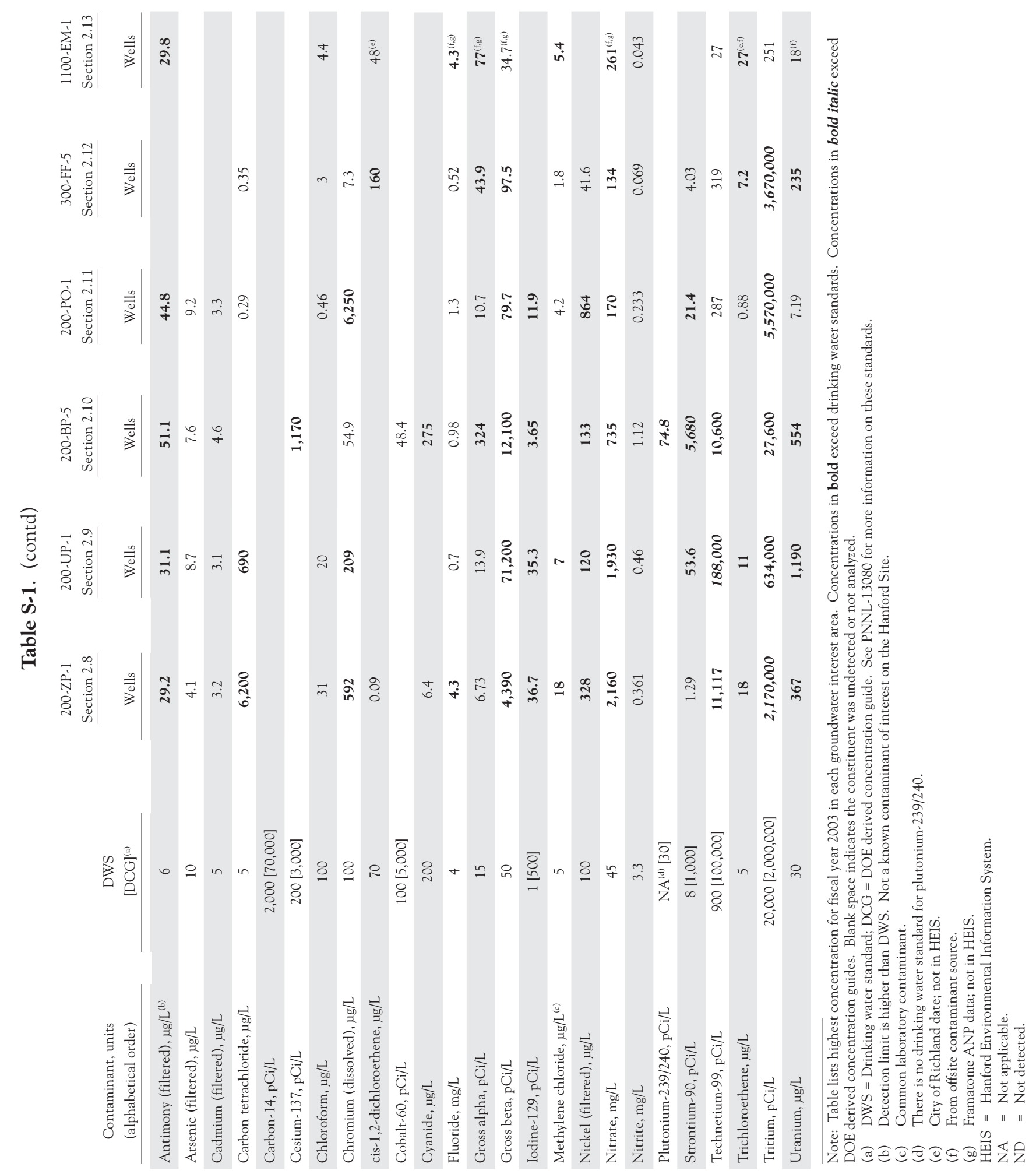




\section{Tritium \\ concentrations \\ increased in some \\ 100-K Area wells \\ in fiscal year 2003.}

strontium-90 exceeded drinking water standards in several wells. Nitrate and chromium were somewhat elevated, but have been below drinking water standards in recent years.

EPA approved a new sampling and analysis plan at the end of September 2003. The new plan, which is being implemented in fiscal year 2004, revises the monitoring program slightly and calls for the addition of more aquifer sampling tubes to monitor contaminants near the Columbia River. There is no active groundwater remediation in the 100-B/C Area.

\section{0-KR-4 Operable Unit}

The principal groundwater issues in this operable unit include (a) chromium contamination associated with past disposal to an infiltration trench near the river, (b) monitoring near K Basins, which have contaminated groundwater in the past with tritium, and (c) tritium associated with a burial ground. In addition to chromium and tritium, constituents of concern include carbon-14, strontium-90, technetium-99, nitrate, and trichloroethene.

CERCLA Interim Action. A pump-and-treat system operates as a CERCLA interim action to reduce the amount of chromium entering the Columbia River at $100-\mathrm{K}$ Area. Two new extraction wells, one new injection well, and one new monitoring well were installed in fiscal year 2003. Also, an existing monitoring well was converted to an extraction well.

Chromium concentrations appear to be decreasing with time as a result of pump-andtreat operation and the attenuation of the plume by natural processes, such as dispersion. Concentrations remained above the remediation goal $(22 \mu \mathrm{g} / \mathrm{L})$ in most of the compliance wells, however.
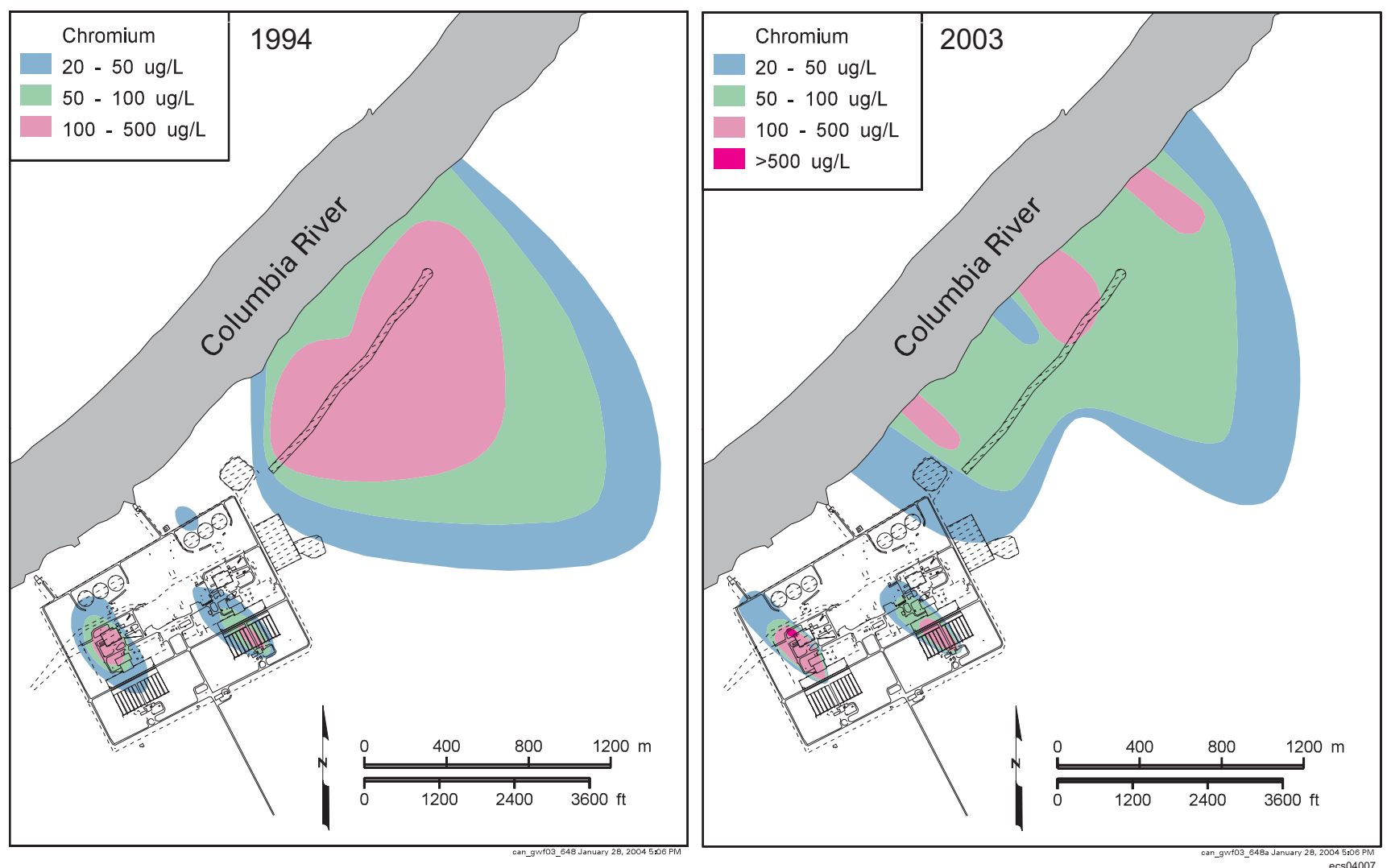

A pump-and-treat system in the 100-K Area reduces the amount of chromium entering the Columbia River. Concentrations decreased in most areas since 1994. 
K Basins. Tritium concentrations increased sharply in fiscal year 2003 in several wells near the basins. The locations of the wells, groundwater flow direction, and concentrations of co-contaminants indicate the increases in tritium were caused by infiltration through former cribs and do not represent new leakage from the basins.

Results of a soil-gas survey conducted near a 100-K Area burial ground in fiscal year 2003 indicated the presence of tritium in the vadose zone as well as in the underlying groundwater.

\section{0-NR-2 Operable Unit}

The primary groundwater contaminant in the 100-N Area is strontium-90, which originated at two liquid waste disposal cribs. The extent of the plume has changed little in over 12 years; however, concentrations increased during the 1990s because of changing water levels and the end of effluent discharge. Tritium also was present in waste discharged to the 100-N cribs. Tritium concentrations in groundwater are declining, and the plume is shrinking. Nitrate, sulfate, and petroleum hydrocarbons also are present in 100-N Area groundwater.

CERCLA Interim Action. A pump-and-treat system in the 100-N Area operates to reduce the movement of strontium-90 toward the Columbia River. Since strontium-90 binds to sediment grains, pump-and-treat is not an effective way to clean up the aquifer. Concentrations remained far above the drinking water standard in fiscal year 2003. DOE is investigating alternative methods for remediation of the strontium-90 plume.

116-N-1, 116-N-3, 120-N-1, and 120-N-2 (1301-N, 1325-N, 1324-N/NA) Facilities. Four RCRA units are located in the 100-N Area. During fiscal year 2003, RCRA monitoring indicated that these sites are not contaminating groundwater with non-radioactive,

\section{Pump-and-treat is not an effective way to clean up strontium-90 contamination.}
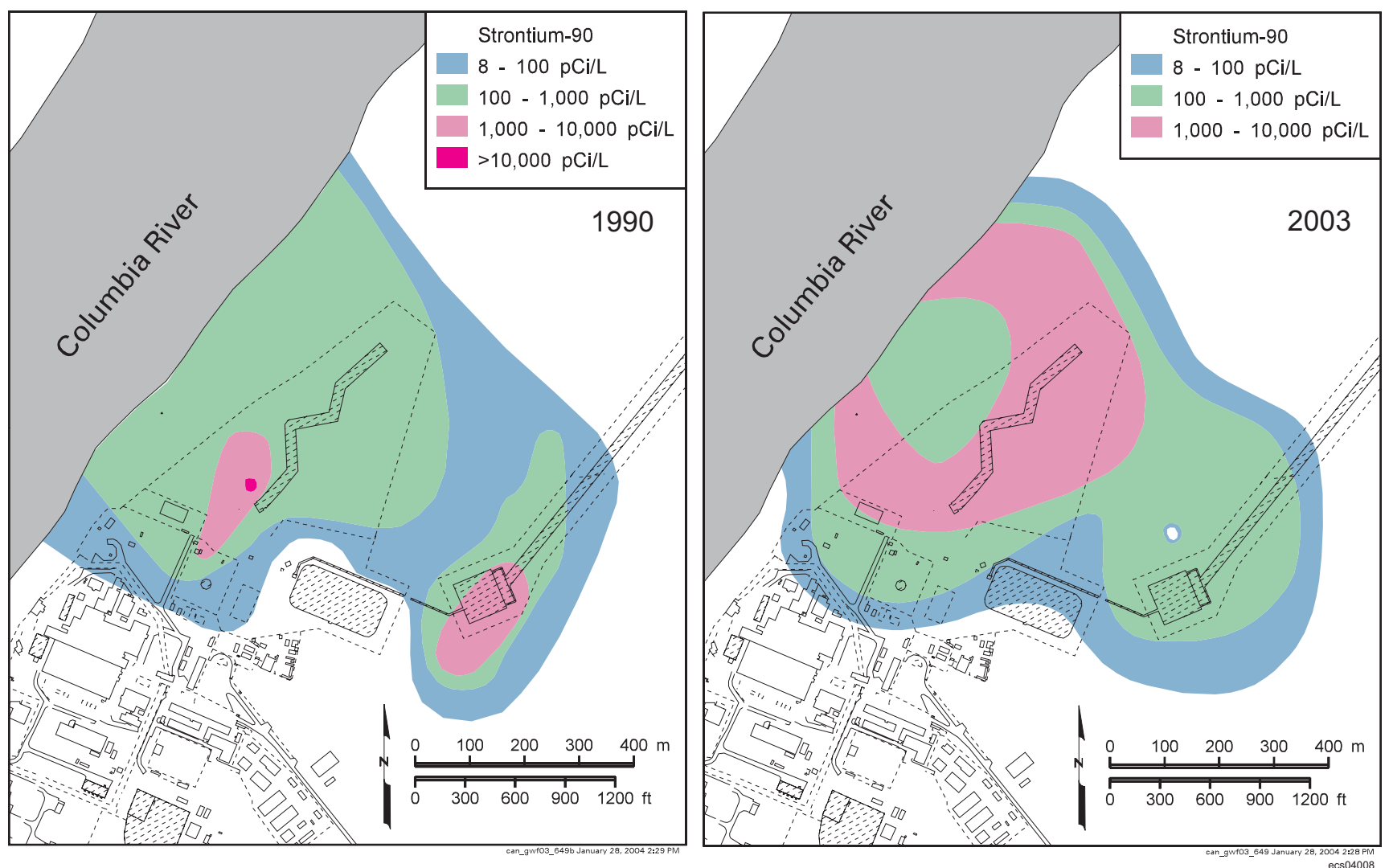

Concentrations of strontium-90 in the 100-N Area increased after 1990, but the overall shape of the plume remained about the same in 2003. 


\section{Chromium concentrations are increasing in the central 100-D Area.}

hazardous constituents. However, the $120-\mathrm{N}-1$ percolation pond added sulfate, a nonhazardous constituent, to the groundwater.

\section{0-HR-3-D Operable Unit}

The 100-HR-3 Operable Unit underlies the 100-D and 100-H Areas and the region between. Hexavalent chromium is the primary contaminant of concern in the 100-D Area. The source of this contaminant was sodium dichromate added to reactor cooling water to inhibit corrosion, which was discharged to cribs and ditches. Chromium is distributed in two plumes that have merged in recent years. Other contaminant plumes include tritium, nitrate, and sulfate.

CERCLA Interim Actions. The north chromium plume is the target of a pump-andtreat system, which is designed to reduce the amount of chromium entering the Columbia River. In fiscal year 2003, concentrations remained above the remediation goal ( $22 \mu \mathrm{g} / \mathrm{L})$ in compliance wells. The southwest chromium plume is being remediated with an in situ system that immobilizes chromium in the aquifer. Chromium concentrations downgradient of the remediation system have declined in some wells and aquifer tubes; however, levels remained above the remediation goal $(20 \mu \mathrm{g} / \mathrm{L})$.

In fiscal year 2003, chromium concentrations increased in the central 100-D Area, bypassing both remediation systems. DOE and regulators are working together to expand the remediation systems so they intercept the changing plume.
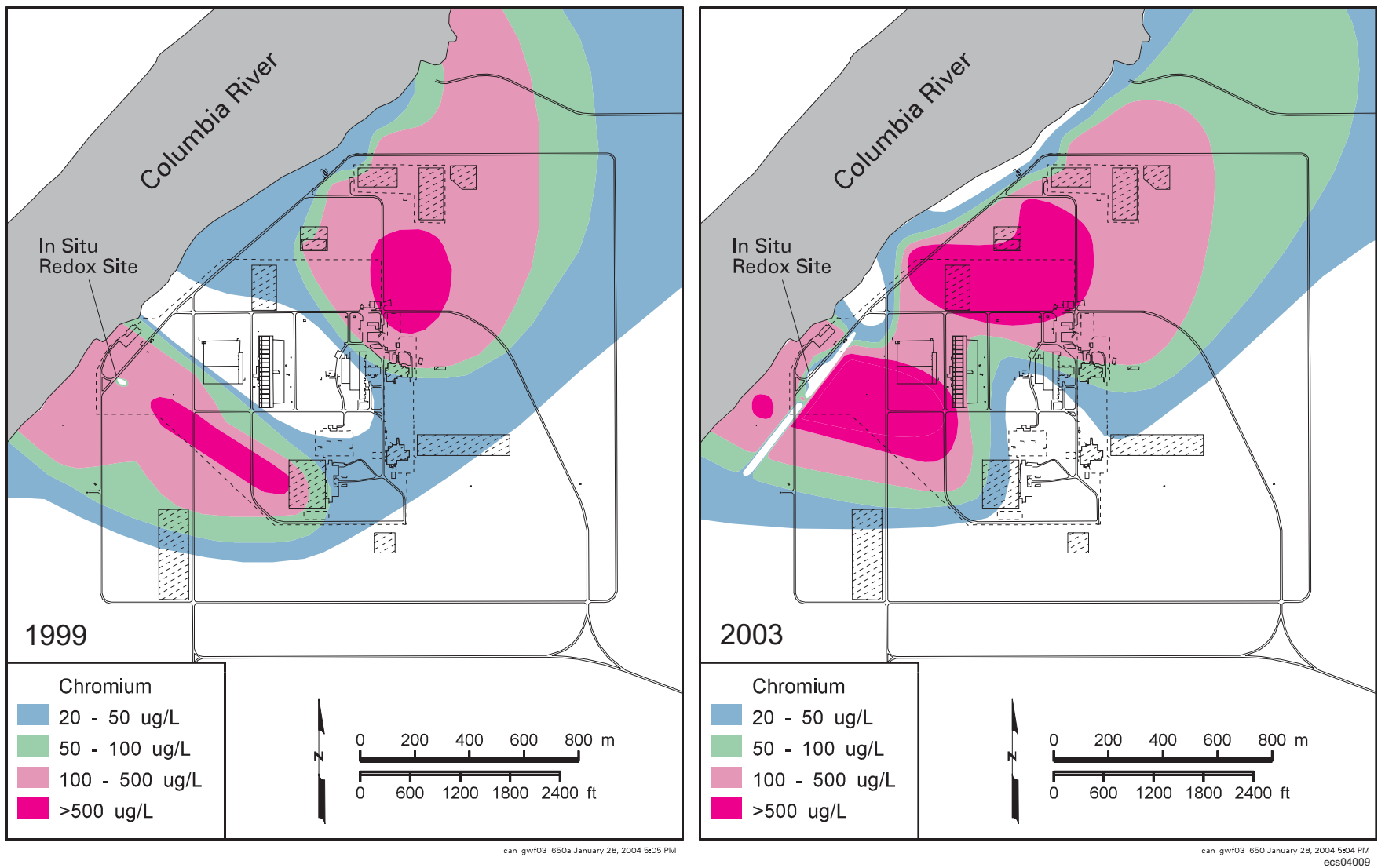

To decrease the amount of chromium entering the Columbia River in the 100-D Area, DOE operates a pump-andtreat system in the north and an in situ treatment system in the south. Chromium contamination has moved into the central 100-D Area in recent years, beyond the influence of either remediation system. DOE will expand the interim remedial action to intercept the central part of the plume near the river. 


\section{0-HR-3-H Operable Unit}

The east part of the 100-HR-3 Operable Unit underlies the 100-H Area. Hexavalent chromium is the primary constituent of concern, but the plume is smaller and concentrations are lower than in the 100-D Area. Nitrate also is elevated, but concentrations have declined from their peak levels. Strontium-90 exceeds the drinking water standard beneath former retention basins. Technetium-99 and uranium are elevated in a small area.

CERCLA Interim Action. The chromium plume is the target of a pump-and-treat system. Chromium concentrations have decreased in recent years due to remediation and natural processes. However, concentrations in some compliance wells remained above the remediation goal $(22 \mu \mathrm{g} / \mathrm{L})$.

116-H-6 (183-H) Evaporation Basins. These former basins are the only RCRA site in the 100-H Area. Leakage from the basins contaminated groundwater with chromium, nitrate, technetium-99, and uranium. The site is monitored during the post-closure period to track contaminant trends during the operation of the CERCLA interim action for chromium.

\section{0-FR-3 Operable Unit}

Nitrate exceeds the drinking water standard beneath much of the 100-F Area and the downgradient region. Other groundwater contaminants include strontium-90 and trichloroethene.
Interim remedial actions in the 100 Areas reduce

the amount of

hexavalent

chromium entering

the Columbia

River.
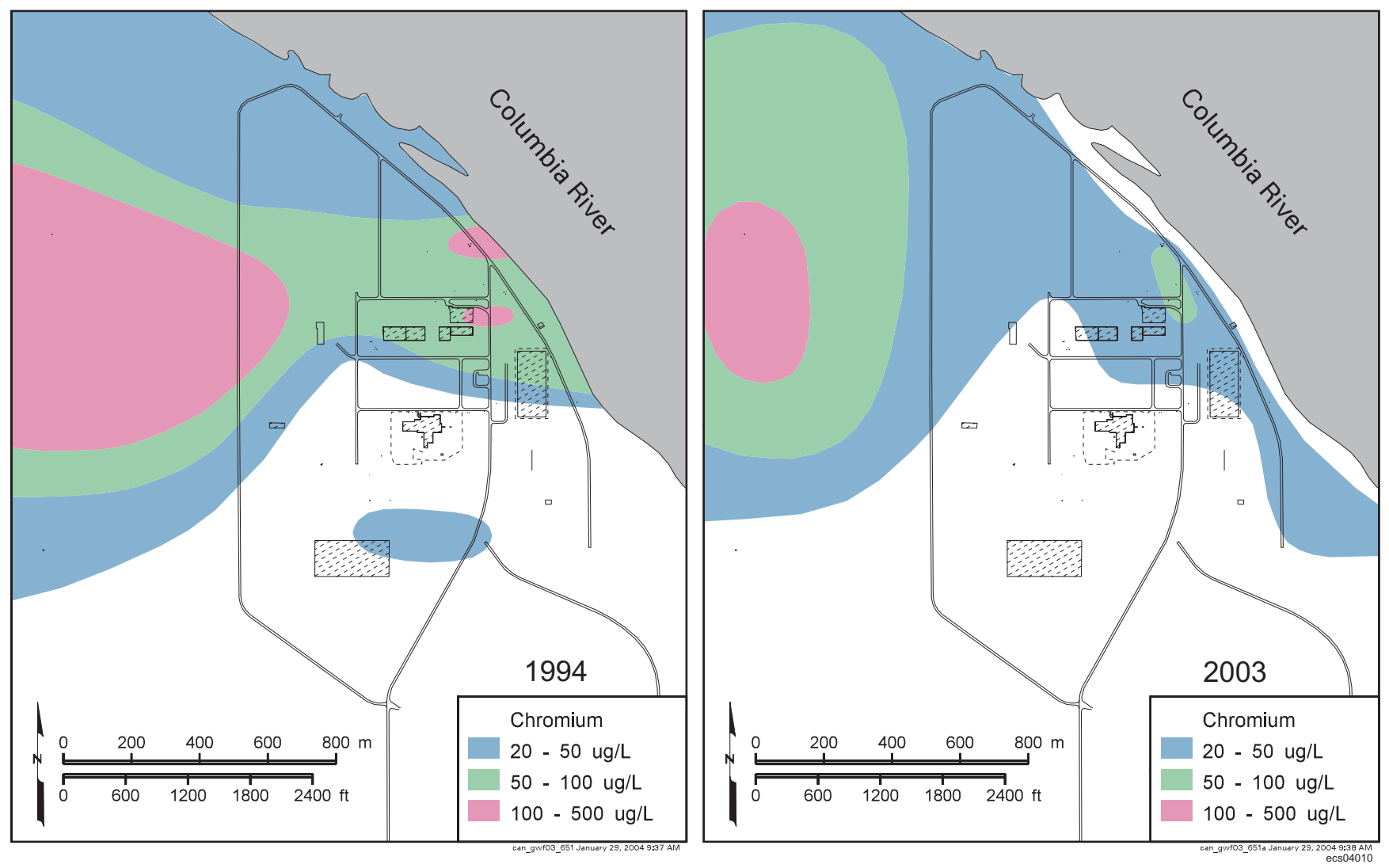

A pump-and-treat system in the $100 \mathrm{H}$-Area reduces the amount of chromium entering the Columbia River. Between 1994 and 2003, concentrations decreased through most of the plume. The decrease is the result of remediation and natural processes. 


\section{A pump-and-treat \\ system prevents the spread of the high- \\ concentration \\ portion of the \\ carbon \\ tetrachloride \\ plume.}

EPA approved a new sampling and analysis plan at the end of September 2003. The new plan, which is being implemented in fiscal year 2004, revises the monitoring program slightly and calls for the addition of more aquifer sampling tubes to monitor contaminants near the Columbia River. There is no active groundwater remediation in the 100-FR-3 Operable Unit.

\section{0-ZP-1 Operable Unit}

This operable unit encompasses the northern portion of the 200 West Area. The primary contaminant of concern is carbon tetrachloride, which forms the largest plume of chlorinated hydrocarbons on the Hanford Site. The contamination is principally from waste disposal associated with the Plutonium Finishing Plant, where organic chemicals were used to process plutonium. Trichloroethene and chloroform also are associated with this plume. Other contaminants include tritium, nitrate, chromium, fluoride, iodine-129, technetium-99, and uranium.

There are four RCRA sites, one other regulated unit, and one CERCLA interim action for groundwater in the 200-ZP-1 Operable Unit:

CERCLA Interim Action. A groundwater pump-and-treat system is operating in this operable unit to prevent the spread of the central, high-concentration portion of the carbon tetrachloride plume. The remediation is proving effective, and the plume has shrunk at the 4,000- $\mu \mathrm{g} / \mathrm{L}$-plume contour.
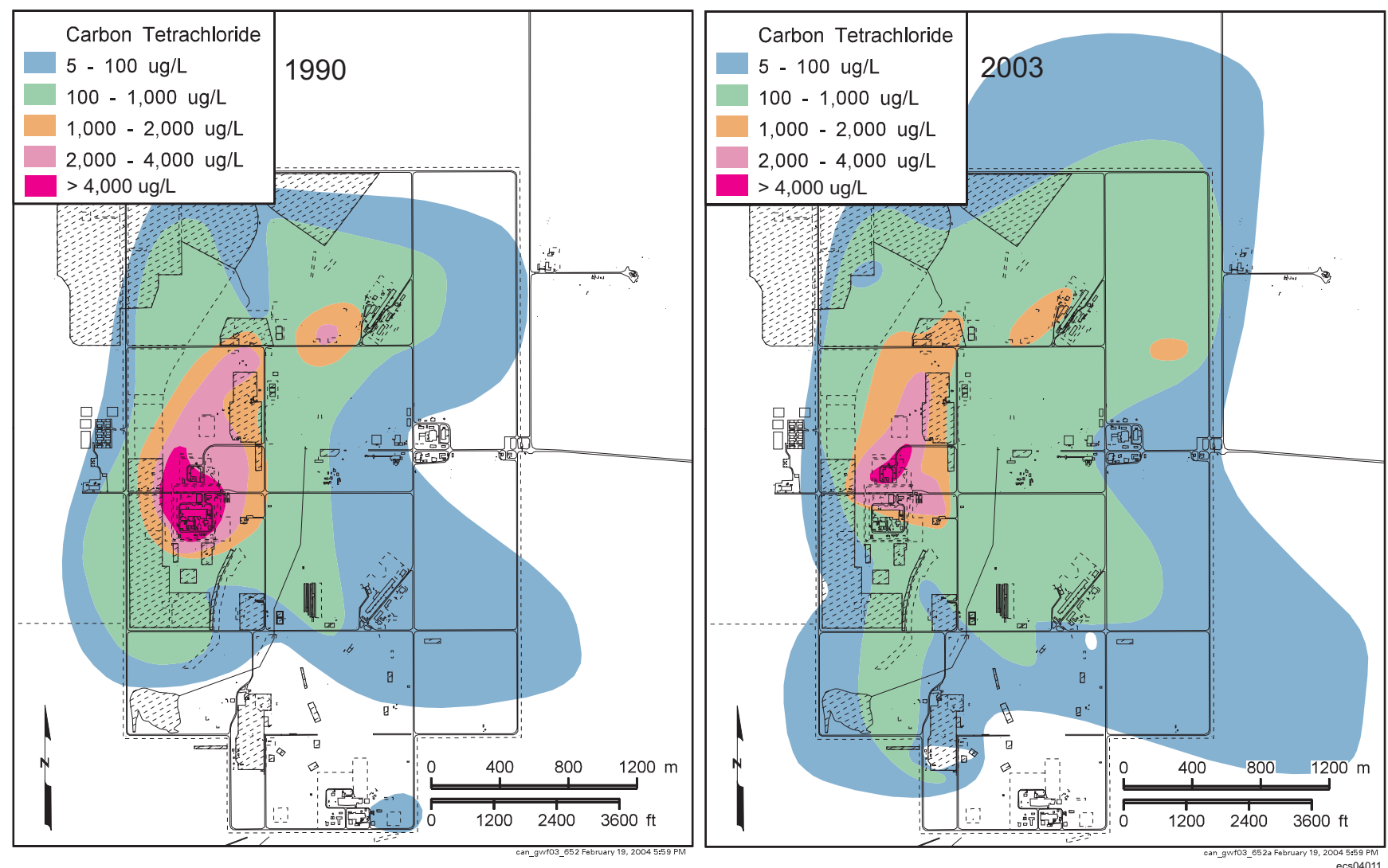

The carbon tetrachloride plume beneath the 200 West Area spread between 1990 and 2003. Since 1996, a pumpand-treat system is helping prevent further spreading of the heart of the plume, shown here in pink and red. 
Low-Level Burial Grounds Waste Management Areas 3 and 4. Groundwater monitoring under interim status requirements continued in fiscal year 2003. Monitoring results indicate no releases attributable to these waste management areas.

A downgradient monitoring well for Waste Management Area 4 went dry in fiscal year 2003. Monitoring networks for both of these waste management areas contain fewer than the optimal number of wells for monitoring.

In June 2002, DOE submitted an application to incorporate the low-level burial grounds into the Hanford Facility RCRA Permit. As part of the application, new groundwater monitoring wells, constituents, and statistical evaluations are proposed. Workshops with Ecology to address this application began in fiscal year 2003.

Waste Management Area $T$. Results of groundwater quality assessment monitoring continued to suggest that the waste management area has not contributed to dangerous waste contamination of the uppermost aquifer in the area. Carbon tetrachloride, trichloroethene, chromium, and nitrate are present in groundwater, but the contamination is believed to have originated at other facilities.

Waste Management Area TX-TY. Assessment monitoring continued in fiscal year 2003. Chromium concentrations are elevated in groundwater; the most likely source is the waste management area. However, other sources of chromium contamination are located nearby. Some nitrate contamination may be from Waste Management Area TX-TY, but other sources nearby clearly have contributed. Carbon tetrachloride and trichloroethene contamination from other sources also is present.

State-Approved Land Disposal Site. This active disposal facility is regulated under a state waste discharge permit. Groundwater is monitored for tritium and 15 other constituents. Concentrations did not exceed permit enforcement limits during fiscal year 2003.

\section{0-UP-1 Operable Unit}

This operable unit underlies the south 200 West Area. The primary contaminants of concern are technetium-99 and uranium. Tritium, iodine-129, and nitrate plumes have origins in this operable unit. Sources of carbon tetrachloride were primarily within the 200-ZP-1 Operable Unit, but the contamination underlies the 200-UP-1 Operable Unit as well.

There are four RCRA sites, one CERCLA interim action, and a CERCLA disposal site in the 200-UP-1 Operable Unit. Monitoring activities are summarized below.

CERCLA Interim Action. A groundwater pump-and-treat system is operating near U Plant to contain the technetium-99 and uranium plumes there. During the fiscal year, the high concentration portions of the technetium- 99 and uranium plumes $(9,000 \mathrm{pCi} / \mathrm{L}$ and $480 \mu g / L$ contours, respectively) were hydraulically contained. Although more sampling is required to confirm the trend, technetium-99 appears to have been remediated to below the remediation goal at all wells in the baseline plume area. Uranium concentrations remained above the remediation goal in one well.

During the fiscal year, one monitoring well in the baseline area went dry, leaving only one monitoring well to track plume behavior. Two wells went dry in another portion of the operable unit. A new monitoring well was installed south of the baseline plume area to replace another dry well.

216-U-12 Crib. Assessment monitoring continued in fiscal year 2003. The crib is one of several sources that have contributed to a nitrate plume in the area. Closure of the crib will be coordinated with and conducted under CERCLA. The monitoring network contains just two useable downgradient wells and no upgradient wells.

216-S-10 Pond and Ditch. Indicator parameter data have not indicated that the 216-S-10 facility has affected groundwater quality in the uppermost aquifer beneath the
Pump-and-treat

systems in the

200 West Area are

interim actions for

groundwater

remediation until a

final remedy can be

identified.

A groundwater

pump-and-treat

system is operating

near U Plant to

contain the

technetium-99 and

uranium plumes

there. The high

concentration

portions of the

plumes were

hydraulically

contained. 

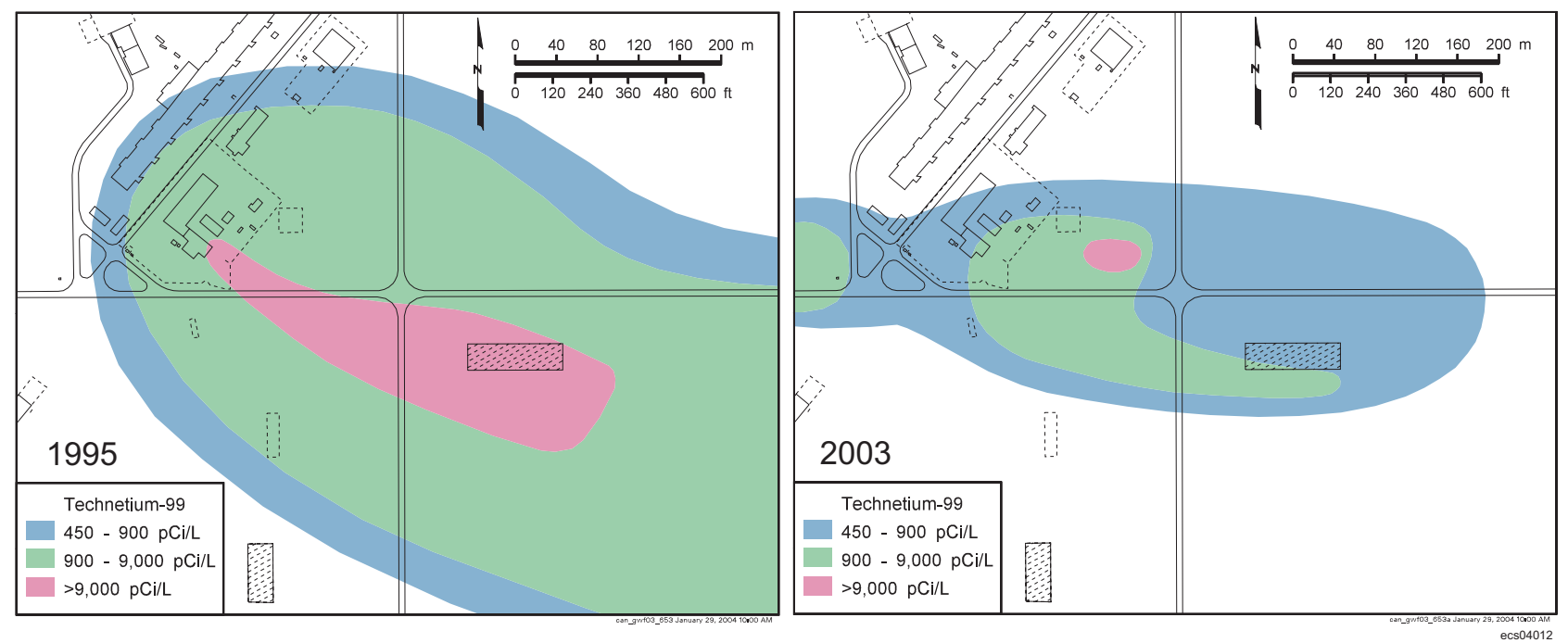

A pump-and-treat system at the 200-UP-1 Operable Unit (200 West Area) has decreased the size of the technetium-99 plume. The system began to operate in fall 1995. However, many monitoring wells in the plume have gone dry, making interpretation of plume size less certain.
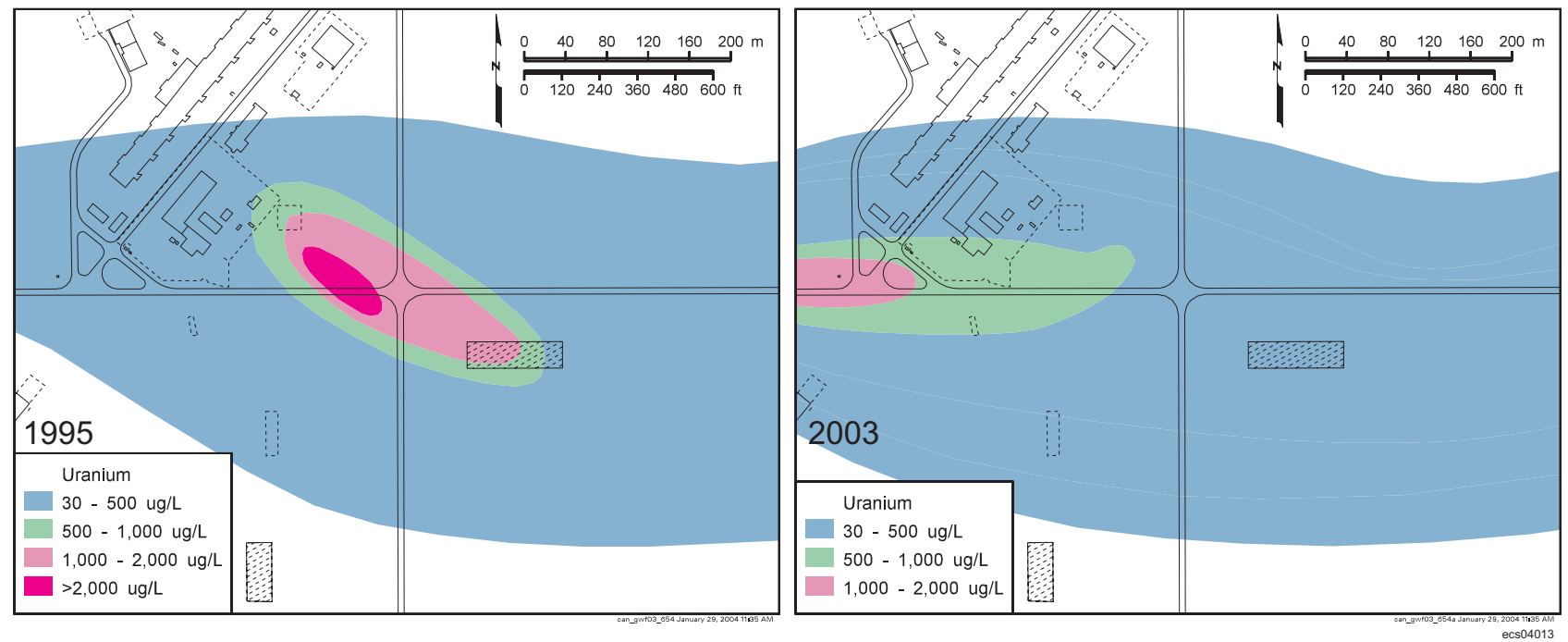

Uranium contamination in the 200-UP-1 Operable Unit (200 West Area) is not responding to the pump-and-treat system as quickly as the technetium-99. Unlike technetium-99, uranium interacts with sediment grains, slowing its movement and response to remediation.

site. In fiscal year 2003, one well went dry and a new well was installed. The current RCRA monitoring network consists of only two downgradient wells.

Waste Management Area S-SX. Assessment monitoring continued in fiscal year 2003. Results continued to indicate that sources within the tank farms have contaminated groundwater with chromium. Concentrations of nitrate, chromium, and the non-RCRAregulated constituent technetium-99 increased significantly during the year in one monitoring well. At the request of Ecology, the practice of purging at least 4,546 liters of water from the well after each quarterly sampling event was started in March 2003. Data from a vertical sampling study in the same well show that pumped water is a blend of water entering the well from all parts of the screened interval. Therefore, the vertical location of 
the sample pump intake does not have a significant effect on measured constituent concentrations, as long as the well is purged adequately before a sample is collected.

Waste Management Area $\boldsymbol{U}$. Assessment monitoring continued in fiscal year 2003. The waste management area has affected groundwater quality with nitrate and possibly chromium. During fiscal year 2003, nitrate concentrations continued to increase in downgradient wells in the south half of the waste management area.

Environmental Restoration Disposal Facility. Results of groundwater monitoring continued to indicate that the facility has not adversely impacted groundwater quality. Higher concentrations of gross beta and unfiltered chromium were detected in fiscal year 2003. Future results will be evaluated to confirm any increasing trends.

\section{0-BP-5 Operable Unit}

This operable unit includes groundwater beneath the north 200 East Area. A technetium-99 plume extends northward between Gable Mountain and Gable Butte. Other contaminants include uranium, iodine-129, cobalt-60, cyanide, strontium-90, cesium-137, plutonium, tritium, and nitrate.

CERCLA monitoring activities had been interrupted during the past several years in the 200-BP-5 Operable Unit because of waste management issues. Sampling activities resumed in late fiscal year 2003 following approval of new sampling and analysis and waste control plans. There is no active groundwater remediation in this operable unit.

There are five RCRA sites in the 200-BP-5 Operable Unit. Monitoring activities are summarized below.

Waste Management Area B-BX-BY. Assessment monitoring continued at this site in fiscal year 2003. Contamination observed in downgradient wells around this waste management area primarily is due to vertical movement of residual waste left in the soil under the tank farms.

Waste Management Area $\boldsymbol{C}$. This site continued to be monitored under an interim status indicator evaluation program in fiscal year 2003. Indicator parameters did not exceed critical mean values. Four new monitoring wells were installed.

\author{
A technetium-99 \\ plume extends from \\ the 200 East Area \\ to the north.
}

\begin{tabular}{|c|c|c|c|c|}
\hline \multicolumn{5}{|c|}{ Area of Contaminant Plumes at Levels Above Drinking Water Standards (square kilometers) } \\
\hline $\begin{array}{c}\text { Constituent } \\
\text { (drinking water standard) }\end{array}$ & $\begin{array}{l}\text { Fiscal Year } \\
2000\end{array}$ & $\begin{array}{l}\text { Fiscal Year } \\
2001\end{array}$ & $\begin{array}{l}\text { Fiscal Year } \\
2002\end{array}$ & $\begin{array}{l}\text { Fiscal Year } \\
2003\end{array}$ \\
\hline Carbon tetrachloride $(5 \mu \mathrm{g} / \mathrm{L})$ & 9.8 & 9.8 & 9.9 & 10.6 \\
\hline Chromium (100 pg/L) & 2.8 & 2.8 & 2.6 & 2.6 \\
\hline lodine-129 (1 pCi/L) & 89.6 & $79.5^{(a)}$ & 79.4 & 75.5 \\
\hline Nitrate $(45 \mathrm{mg} / \mathrm{L})$ & 36.3 & 38.4 & 35.7 & 36.2 \\
\hline Strontium-90 (8 pCi/L) & 2.8 & 2.7 & 2.7 & 2.6 \\
\hline Technetium-99 (900 pCi/L) & 2.3 & 2.4 & 2.3 & 2.3 \\
\hline Trichloroethene (5 $\mu \mathrm{g} / \mathrm{L})$ & 4.2 & 4.3 & $3.4^{(a)}$ & 3.4 \\
\hline Tritium $(20,000 \mathrm{pCi} / \mathrm{L})$ & 152 & 151 & 142 & 136 \\
\hline Uranium $(20 / 30 \mu g / L)^{(b)}$ & 2.0 & 1.6 & 1.5 & 1.4 \\
\hline Combined Plumes & 210 & 208 & 196 & 190 \\
\hline \multicolumn{5}{|c|}{$\begin{array}{l}\text { (a) These large changes in estimates of plume area are caused by changing interpretations of the data and changes to } \\
\text { the monitoring network. Changes in actual plume size are usually more gradual. } \\
\text { (b) Area of uranium plume based on } 20 \mathrm{mg} / \mathrm{L} \text { standard in } 2000 \text { and } 30 \mathrm{mg} / \mathrm{L} \text { standard in subsequent years. }\end{array}$} \\
\hline
\end{tabular}



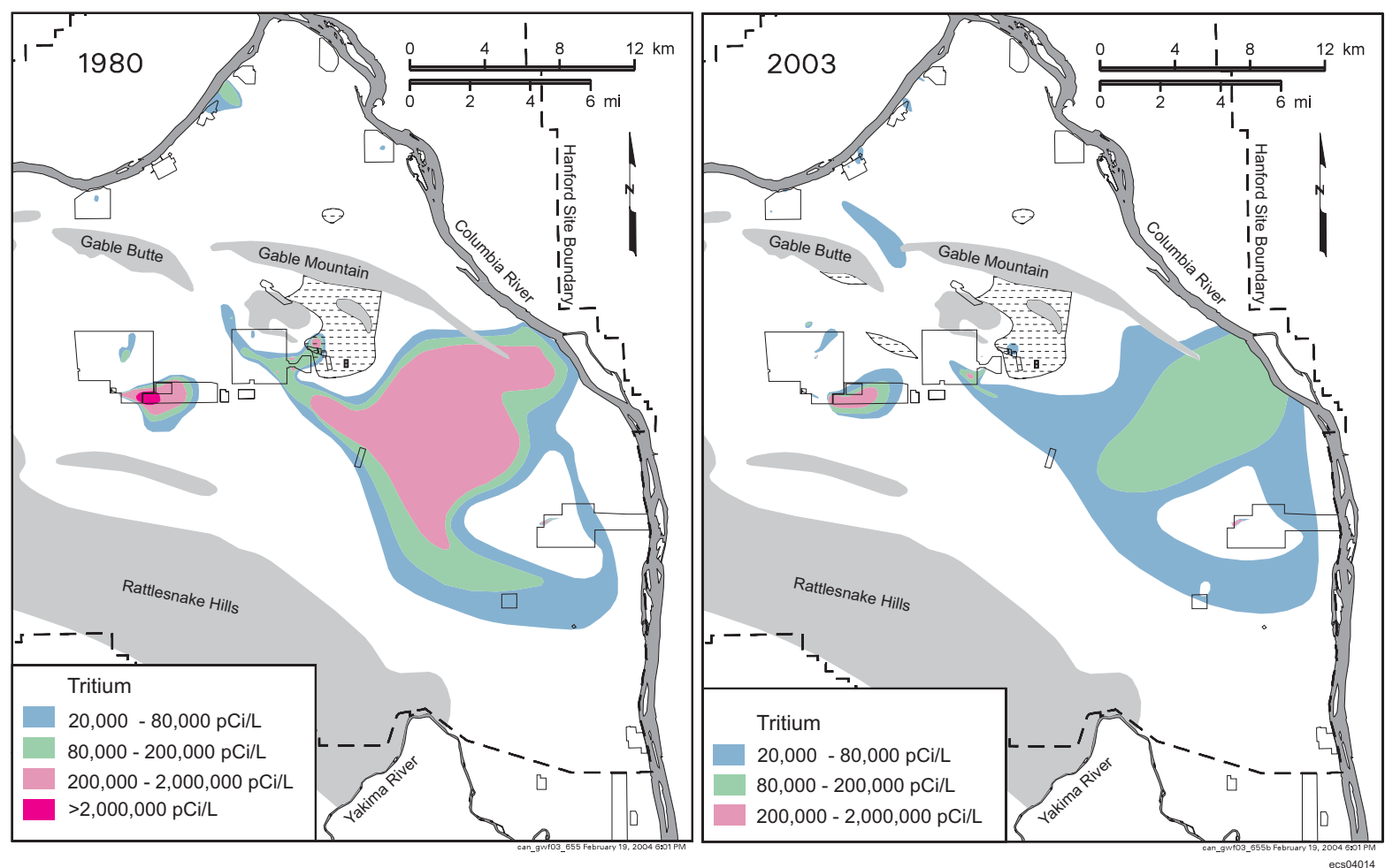

Site-wide tritium plumes in 1980 and 2003 are shown in the above maps. Concentrations in the heart of the plume have decreased over the years; the south margin has ceased its southward migration.

Tritium

concentrations

generally are

decreasing

southeast of the

200 East Area.
216-B-63 Trench. Results of interim status detection monitoring continued to support the interpretation that this facility has not impacted groundwater with hazardous constituents.

Low-Level Waste Management Areas 1 and 2. Groundwater monitoring under interim status requirements continued at these RCRA sites in fiscal year 2003. Monitoring results indicated no releases attributable to these waste management areas.

In June 2002, DOE submitted an application to incorporate the low-level burial grounds into the Hanford Facility RCRA Permit. As part of the application, new groundwater monitoring wells, constituents, and statistical evaluations are proposed. Workshops with Ecology to address this application began in fiscal year 2003.

Liquid Effluent Retention Facility. A 2001 letter from Ecology directed DOE to discontinue statistical evaluation of groundwater sample results because all but two wells have gone dry. DOE has continued to sample the two remaining wells and is exploring alternative approaches to monitoring the facility.

\section{0-PO-1 Operable Unit}

This operable unit encompasses the south portion of the 200 East Area and a large portion of the Hanford Site extending to the east and southeast. The operable unit encompasses widespread plumes of tritium, nitrate, and iodine-129. Concentrations of tritium continued to decline as the plume attenuates naturally due to radioactive decay and dispersion. Other contaminants include strontium-90 and technetium-99, but these are limited to very small areas.

During fiscal year 2003, a draft sampling and analysis plan for the operable unit was prepared and submitted to the regulator. The new plan was approved in fiscal year 2004. 
There are six RCRA sites and three other regulated units in the 200-PO-1 Operable Unit:

PUREX Cribs. Three cribs (216-A-10, 216-A-36B, and 216-A-37-1) are monitored jointly under a RCRA interim status assessment program. The cribs have contributed to widespread contaminant plumes in the area, including nitrate and the non-RCRA constituents tritium and iodine-129. The nitrate plume is generally attenuating throughout most of its area, except near the PUREX cribs. In recent years, the concentration of nitrate in near-field wells at the PUREX cribs has either held steady or increased.

During fiscal year 2003, one monitoring well at the PUREX cribs went dry. An existing well was added to the network to replace the dry well.

Waste Management Area $\boldsymbol{A}-\boldsymbol{A X}$. This RCRA site continued to be monitored under an interim status indicator evaluation program in fiscal year 2003. Indicator parameters did not exceed critical mean values. Two new monitoring wells were installed.

216-A-29 Ditch. The groundwater beneath this site is monitored as required by interim status detection regulations. To date, the facility has not contaminated groundwater with regulated constituents, although sulfate attributable to manmade sources has been detected in two wells.

Integrated Disposal Facility. This planned facility will be an expandable, lined, RCRA-compliant landfill. Construction is scheduled to begin in 2004. The Part B permit application was submitted to Ecology and is scheduled to be incorporated into the Hanford Facility RCRA Permit in 2004. Four out of seven monitoring wells have been installed.

216-B-3 Pond. This RCRA site continued to be monitored under a temporary, alternative monitoring plan in fiscal year 2003. In fiscal year 2001, the regulator granted a variance to apply a new approach to groundwater monitoring for a 2-year trial period. The trial approach uses statistical methods based on within-well comparisons instead of the standard upgradient/downgradient comparisons. The final samples for the trial period were collected in July 2003, and an evaluation of the approach is currently underway.

Nonradioactive Dangerous Waste Landfill. This RCRA site is located in the 600 Area, within the footprint of the 200-PO-1 regional plume. During fiscal year 2003, interim status detection monitoring continued to show no evidence of contamination from this facility.

Solid Waste Landfill. This facility is regulated under state dangerous waste regulations. In fiscal year 2003, specific conductance, $\mathrm{pH}$, chloride, and sulfate exceeded their background threshold levels in one or more samples.

200 Area Treated Effluent Disposal Facility. A state waste discharge permit governs groundwater sampling and analysis in the three monitoring wells at this facility. No permit criteria for constituents in groundwater were exceeded in fiscal year 2003. The groundwater monitoring network continues to show that effluent from the facility is not taking a direct route to the uppermost aquifer, which is confined.

4608 B/C Process Ponds. The 4608 B/C ponds (also called the 400 Area process ponds), are regulated under a state waste discharge permit. Groundwater quality met permit conditions in fiscal year 2003. The permit was recently modified, and groundwater monitoring was no longer required as of October 1, 2003.

\section{0-FF-5 Operable Unit}

This operable unit is divided into two general regions: the 300 Area and the 300-FF-5 North region, which includes the 618-11 burial ground, the 618-10 burial ground, and the 316-4 cribs.

Constituents from 300 Area sources include uranium and volatile organic compounds. The size of the 300 Area uranium plume is generally consistent from year to year, but concentrations are variable throughout the year as a result of changes in river stage. A plume
In some areas, DOE and the regulators agree that natural processes will clean up groundwater contamination.

Groundwater is monitored throughout the process to determine if concentrations are falling, as expected. This approach is being applied in the 300 Area and 1100-EM-1 Operable Unit. 


\section{Trichloroethene concentrations continued to be below the cleanup level in the 1100-EM-1 Operable Unit.}

\section{Confined aquifers}

are capped by less permeable layers that cannot transmit much water. Confined aquifers at Hanford occur beneath clay or basalt layers. of trichloroethene in the 300 Area is attenuating naturally, and average concentrations remained below the drinking water standard in fiscal year 2003. Trichloroethene contamination in this area is associated with other hydrocarbons (e.g., cis-1,2-dichloroethene). Strontium-90 is elevated in a single well. The interim action chosen for the 300-FF-5 Operable Unit includes natural attenuation of the uranium and organic contamination in the 300 Area.

Contaminants from the north part of the operable unit include tritium, uranium, various volatile organic compounds, petroleum hydrocarbons, and tributyl phosphate. Tritium concentrations in groundwater near the 618-11 burial ground have decreased in recent years but remained among the highest on the Hanford Site during fiscal year 2003. This high-concentration contamination is limited to a narrow plume extending $\sim 1$ kilometer to the east.

316-5 Process Trenches. This former disposal facility is the only RCRA site in the 300-FF-5 Operable Unit. The trenches have contributed to groundwater contamination, which will be remediated under CERCLA. While the CERCLA interim action (natural attenuation) is in progress, the trenches are monitored under a final status, corrective action monitoring program.

\section{0-EM-1 Operable Unit}

This operable unit includes a small, narrow plume of trichloroethene, which is attenuating naturally. Annual average concentrations have remained below the drinking water standard since fiscal year 2001. Contaminants also flow into the area from offsite sources (e.g., nitrate from agriculture and industry).

The city of Richland maintains a well field in the 1100-EM-1 groundwater interest area. Wells are monitored frequently to detect any changes in Hanford contaminants near these wells. The tritium plume from the 200 East Area has not been detected in these wells. Low levels of tritium, similar to Columbia River water, continued to be detected.

The selected remedy for 1100-EM-1 Operable Unit groundwater is monitored natural attenuation of volatile organic compounds.

\section{Confined Aquifers}

Although most of Hanford's groundwater contamination is in the unconfined aquifer, DOE monitors wells in deeper aquifers because of the potential for downward migration of contamination and the potential migration of contamination offsite through the basaltconfined aquifer.

The Ringold Formation confined aquifer occurs within fluvial sand and gravel comprising the lowest sedimentary unit of the Ringold formation. It is confined below by basalt and above by the lower mud unit. Groundwater in this aquifer flows generally west to east in the vicinity of the 200 West Area. In the central portion of the aquifer, flow converges on the 200 East Area from the west, south, and east. Groundwater discharges from the confined aquifer into the overlying unconfined aquifer near the 200 East Area.

While effluent disposal was occurring at the B Pond system, groundwater mounding forced groundwater and any associated contamination a limited distance into the Ringold Formation confined aquifer. Groundwater analyses for fiscal year 2003 at the 200 Area Treated Effluent Disposal Facility continued to demonstrate isolation of the confined aquifer from disposal activities.

Within the upper basalt-confined aquifer system, groundwater occurs within basalt fractures and joints, interflow contacts, and sedimentary interbeds. Groundwater in the upper basalt-confined aquifer system generally flows from west to east across the Hanford Site toward the Columbia River.

Results of sampling basalt-confined groundwater show that tritium was detected in some wells at very low levels, while iodine-129, strontium-90, gamma-emitting isotopes, and 
uranium isotopes were not detected. Cyanide, nitrate, and technetium-99 were elevated in one well in the north part of the 200 East Area, but contaminant migration during well construction is responsible for this contamination. Contaminants on the Hanford Site have not migrated through the upper basalt-confined aquifer system to offsite sample locations south and southeast of the Hanford Site.

\section{Well Installation, Maintenance, and Decommissioning}

Ecology, EPA, and DOE negotiated an integrated well drilling list that coordinates and prioritizes the requirements of various groundwater monitoring regulations. During calendar year 2003, a total of 18 new wells were installed at Hanford. These included 7 for RCRA monitoring, 9 for CERCLA operable units, and 2 for research on chromate bioremediation. Two hundred and forty-three wells received maintenance, and sixty-three wells were decommissioned (filled with grout) because they are no longer needed, were in poor condition, or were in the way of remediation sites.

\section{Modeling}

Computer simulations of groundwater flow and contaminant movement help predict future conditions and assess the effects of remediation systems. During fiscal year 2003, modelers calibrated the consolidated groundwater flow and transport site-wide model based on an alternative conceptual model.

The System Assessment Capability is an integrated assessment tool that includes several linked computer models designed to simulate the movement of contaminants from waste sites through the vadose zone, groundwater, and Columbia River to receptors. It also incorporates modules that calculate the risks to human health and the environment. During fiscal year 2003, the System Assessment Capability was updated; an atmospheric transport module was added and newer versions of the groundwater flow and transport modules were added. The three-dimensional "base case" site-wide groundwater model was used in the initial assessment performed during 2002. In fiscal year 2003, the model grid was refined around the contaminant plume areas.

\section{Vadose Zone}

Subsurface source characterization, vadose zone monitoring, soil-vapor monitoring, and sediment sampling were conducted in fiscal year 2003.

Baseline spectral gamma logging and neutron moisture logging of boreholes continued at selected past-practice, liquid disposal facilities. Subsequent logging events will be compared to this baseline to monitor the movement of subsurface contamination. In fiscal year 2003, logging activities were completed in and around Waste Management Area B-BX-BY.

DOE drilled two new characterization boreholes in the T Tank Farm. The boreholes were placed in the vicinity of the site of the largest documented tank leak in the Hanford Site's history. Spectral gamma logging detected cesium-137, europium-154, europium-152, tin-126, and cobalt-60. Additional results will become available in fiscal year 2004 .

DOE drilled three characterization boreholes in the TX Tank Farm in fiscal year 2002, and results became available in fiscal year 2003. One of the boreholes was drilled to investigate the largest and deepest occurrence of uranium in Waste Management Area TX-TY. Spectral gamma logging detected cesium-137 in that borehole. The other boreholes were drilled to investigate vadose zone contamination related to another past leak site. Spectral gamma logging detected cesium-137, cobalt-60, and uranium-238. Analyses of core samples from the boreholes in TX Tank Farm indicate that the magnitude of
Eighteen new wells were installed on

the Hanford Site in 2003.

Computer models of groundwater help predict movement of contaminants in groundwater and future groundwater conditions. This information is important in planning waste management and cleanup activities at the Hanford Site. 


\section{The results of \\ vadose zone \\ characterization \\ studies improve \\ understanding of \\ the distribution and \\ movement of \\ contamination \\ between the ground \\ surface and the \\ water table.}

contamination is not as great as that found in boreholes at other tank farms. The data do not establish the vertical extent of tank contamination because contamination was found at the bottom of the boreholes.

Boreholes and test pits were excavated to gather characterization data to support remediation of the 216-A-29 ditch, 216-B-63 trench, and 216-S-10 pond and ditch. Spectral gamma logging detected cesium-137 in two of the three boreholes. Additional results will be available in fiscal year 2004 .

Soil vapor was sampled and analyzed near the Plutonium Finishing Plant (200 West Area) to locate carbon tetrachloride release sites with the potential to impact groundwater in the future. Carbon tetrachloride was detected at low concentrations in 6 of the 17 sites sampled. At each of these six sites, the highest concentration was detected in the deepest sample. The relatively low concentrations suggest that there are no active sources of contamination in the upper vadose zone at these locations.

DOE conducted laboratory experiments to help predict the movement of uranium in the vadose zone in the 300 Area. Predicted distribution coefficient values range from 0 to $1 \mathrm{~mL} / \mathrm{g}$ in the near-surface vadose zone and 2 to $4 \mathrm{~mL} / \mathrm{g}$ in unconfined aquifer sediment that is not influenced by dilution with Columbia River water.

Leachate from the Solid Waste Landfill is sampled quarterly. During fiscal year 2003, several analytes continued to be found in the landfill leachate in concentrations above groundwater quality criteria. Chloride and total dissolved solids exceeded groundwater quality criteria for the first time in fiscal year 2003. The volume of leachate generated increased during the year because of above average rainfall during the winter of 2002/2003. Soil gas also is monitored quarterly at the landfill. No contaminants of concern exceeded reporting limits.

Leachate from the Environmental Restoration Disposal Facility continued to be collected and sampled. Selenium, nitrate, gross alpha, gross beta, carbon-14, technetium-99, and uranium showed possible increasing concentration trends over the past 3 years. However, in groundwater, concentrations of these constituents remained stable or decreased, and it appears that the facility has not had an impact on groundwater.

DOE uses geophysical methods to monitor potential movement of contamination beneath single-shell tank farms. During fiscal year 2003, DOE monitored selected boreholes within each of the 12 single-shell tank farms. In general, the contaminated areas appeared to be stable over time.

DOE monitors carbon tetrachloride in soil vapor near vadose zone remediation systems in the 200 West Area. At the end of fiscal year 2003, 78,100 kilograms of carbon tetrachloride had been removed from the vadose zone since extraction operations started in 1991. 


\section{Distribution of Summary Booklet with CD Report}

No. of

Copies

Offsite

S. Arlt

City of Richland

P.O. Box 190

Richland, WA 99352

M. Ault

US Ecology, Inc.

P.O. Box 638

Richland, WA 99352

J. T. Bachmaier

U.S. Department of Energy

Forrestal Building, EH-412

1000 Independence Avenue, S.W.

Washington, D.C. 20585

J. R. Beaver, Mayor

Kennewick City Council

210 West Sixth Avenue

Kennewick, WA 99336

N. Bell

Northwest Environmental Advocates/Hanford Watch

133 Southwest Second Avenue, Suite 302

Portland, OR 97204-3526

M. E. Benitz, Jr.

Benton County Commissioner

620 Market Street

Prosser, WA 99350

J. O. Boda

U.S. Department of Energy

Cloverleaf Building, EM-34

19901 Germantown Road

Germantown, MD 20874-1290

T. D. Bowden

912 N. 48th Street

Seattle, WA 98103

T. E. Carpenter

Government Accountability Project

West Coast Office, Suite 1215

1402 3rd Avenue

Seattle, WA 98101
No. of

Copies

2 Center for Isotope Geochemistry

Lawrence Berkeley National Laboratory

1 Cyclotron Road, Building 70A4418

Berkeley, CA 94720-8179

ATTN: J. N. Christensen

M. Conrad

J. Chasse

Energy Northwest

P.O. Box 968

Richland, WA 99352

2 Confederated Tribes of the Umatilla Indian

Reservation

Environmental Planning/Rights Protection

P.O. Box 638

Pendleton, OR 97801

ATTN: S. Harris

J. H. Richards

D. Crumpler

8208 W. Deschutes Place

Kennewick, WA 99336

G. De Bruler

Columbia River United

P.O. Box 912

Bingen, WA 98605

B. W. Drost

Geological Survey

U.S. Department of the Interior

1201 Pacific Avenue, Suite 600

Tacoma, WA 98402

B. Floyd

for City of Richland

7601 W. Clearwater Avenue, Suite 105

Kennewick, WA 99336

T. Friend

SAIC

3250 Port of Benton Boulevard

Richland, WA 99352

A.J.K. Fyall

Benton County Planning Department

P.O. Box 910

Prosser, WA 99350 
No. of

Copies

H. Gucinski, Chair

Pacific Northwest Natural Area Committee

3200 Jefferson Way

Corvallis, OR 97331

A. Haymaker

1721 Cottonwood Drive

Pasco, WA 99301

R. E. Isaacson

2106 Lee Boulevard

Richland, Washington 99352

R. E. Jaquish

Washington State Department of Health

1232 Vintage Avenue

Richland, WA 99352

R. Jim

Confederated Tribes and Bands of the Yakama Nation

Environmental Restoration/Waste Management

2808 Main Street

Union Gap, WA 98903

2 Idaho National Engineering and Environmental Laboratory

P.O. Box 1625, MS-2107

Idaho Falls, ID 83415-2107

ATTN: J. M. Hubbell J. B. Sisson

K. Klaus

Brookhaven National Laboratory

Building 51

Upton, NY 11973

B. Langille

Duratek Commercial Services

1009 Commerce Park Drive, Suite 100

Oak Ridge, TN 37830

R. J. Leaumont

Lower Columbia Basin Audubon Society

9016 Sunset Terrace

Pasco, WA 99301

D. Leavitt

Science and Engineering Assoc. Inc.

3205 Richards Lane, Suite A

Santa Fe, NM 87507
No. of

$\underline{\text { Copies }}$

J. Loving

U.S. Department of Energy

Forrestal Building, Room 3E094

1000 Independence Avenue, S.W.

Washington, DC 20585

L. Maas

Framatome ANP Richland, Inc.

2101 Horn Rapids Road

Richland, WA 99352

S. McDaniel

South Columbia Basin Irrigation District

P.O. Box 1006

Pasco, WA 99301

K. Moser

Vista Engineering Technologies

8203 W. Quinault, Building C, Suite 200

Kennewick, WA 99336

S. McNutt

City of Richland

3102 Twin Bridges Road

Richland, WA 99352

2 Nez Perce Tribe

Environmental Restoration/Waste Management

P.O. Box 365

Lapwai, ID 83540-0365

ATTN: L. Lilligren

P. Sobotta

2 K. Niles

State of Oregon Office of Energy

625 Marion Street N.E.

Salem, OR 97310

R. Patt

1655 S. Elm $\# 405$

Canby, OR 97013

G. M. Pollet

Executive Director

Heart of America, NW

Cobb Building, Suite 208

1305 Fourth Avenue

Seattle, WA 98101 
No. of

Copies

D. Postma

Bureau of Reclamation

U.S. Department of the Interior

P.O. Box 815

Ephrata, WA 98823

R. K. Price

4200 W. 19th

Kennewick, WA 99338

M. Priddy

Washington State Department of Health 309 Bradley Boulevard

Richland, WA 99352

W. Riggsbee

Confederated Tribes and Bands of the

Yakama Nation

1216 W. Kennewick Avenue

Kennewick, WA 99336

J. A. Riley

Washington State Department of Health

P.O. Box 453

Post Falls, ID 83877-0453

J. Rhodrick

U.S. Department of Energy

Cloverleaf Building, EM-43

19901 Germantown Road

Germantown, MD 20874-1290

S. Saldanha

1920 NE Terre View Drive, D 108

Pullman, WA 99163

F. J. Schelling

Sandia National Laboratories

P.O. Box 5800, MS-0779

Albuquerque, NM 87185-0779

J. R. Schinner

11382 Canary Drive

Ijamsville, MD 21754

L. Seelatsee

Wanapum People

Grant County P.U.D.

30 "C" Street S.W.

P.O. Box 878

Ephrata, WA 98823
No. of

$\underline{\text { Copies }}$

M. Sully

Neptune and Company

1505 15th Street, Suite B

Los Alamos, NM 87544

L. C. Treichel

U.S. Department of Energy, EM-43

Cloverleaf Building 2116

19901 Germantown Road

Germantown, MD 20874

J. VanLeer

Cascadia Community College

18345 Campus Way NE

Bothell, WA 98011

M. G. Waddell

Earth Sciences and Resources Institute

University of South Carolina

Columbia, SC 29208

3 Washington State Department of Health

Division of Radiation Protection

P.O. Box 47827

Olympia, WA 98504-7827

ATTN: M. Dunkelman

D. McBaugh

S. VanVerst

P. H. Wicks

North Wind, Inc.

829 Goethals Drive

Richland, WA 99352

L. Williams

Jason Associates

3250 Port of Benton Boulevard

Richland, WA 99352

\section{Onsite}

63 DOE Richland Operations Office

C. A. Babel

H6-60

M. S. Collins

A6-38

T. W. Ferns

A2-17

B. L. Foley

A6-38

J. B. Hall

A2-15

H. B. Hathaway

A2-17

R. D. Hildebrand (20)

A6-38

K. D. Leary 
No. of

Copies

R. G. McLeod

J. G. Morse (10)

J. P. Sands

J. M. Silko

G. L. Sinton

K. M. Thompson (20)

A. C. Tortoso

D. C. Ward

2 DOE Office of River Protection

R. W. Lober

R. M. Yasek

Bechtel Hanford, Inc.

K. R. Fecht

$\mathrm{HO}-02$

2 CH2M HILL Hanford, Inc.

D. A. St. John

R. L. Weiss

H9-02

H9-01

8 CH2M HILL Hanford Group, Inc.
A. Amonette
T. E. Jones
A. J. Knepp
F. Mann
D. A. Myers
D. G. Stock
H. A. Sydnor
C. D. Wittreich

E6-35

E6-35

H6-03

T4-10

E6-35

HO- 50

E6-35

H6-62

3 Duratek Federal Services of Hanford, Inc.

L. P. Diediker

$\mathrm{H} 8-13$

J. A. Winterhalder

R. T. Wilde

E6-35

E6-35

5 Duratek Federal Services, Northwest Operations

J. J. Dorian

H1-11

M. G. Gardner

H1-11

D. J. Moak

H1-11

C. J. Perkins

H1-11

S. H. Worley
No. of

Copies

\section{Fluor Hanford, Inc.}

M. A. Baechler E6-35

J. V. Borghese E6-35

M. E. Byrnes E6-35

C. W. Connell A0-21

R. A. Daughety T4-55

J. D. Davis E6-35

R. A. Del Mar P7-28

D. B. Erb E6-35

B. H. Ford E6-35

J. G. Hogan H1-11

R. L. Jackson E6-35

V. G. Johnson E6-35

L. M. Kelly S4-21

G. G. Kelty E6-35

R. O. Mahood E6-35

K. M. McDonald R3-12

W. J. McMahon E6-35

S. M. Price H8-12

R. F. Raidl E6-35

V. J. Rohay E6-35

L. C. Swanson E6-35

B. Thackaberry E6-35

S. J. Trent A0-21

J. D. Williams R3-62

M. I. Wood H8-44

2 Freestone Environment Services

D. K. Tyler B6-07

M. Serkowski B6-07

3 Stoller

P. D. Henwood B2-62

S. E. Kos B2-62

S. Sobczyk B2-62

3 Washington State Department of Ecology

B. L. Becker-Khaleel B5-18

J. Price B5-18

D. G. Singleton B5-18

81 Pacific Northwest National Laboratory

D. H. Bacon K9-33

M. P. Bergeron K9-36 
No. of

Copies

C. A. Brandt

R. W. Bryce

J. W. Buck

R. J. Cameron

Y. Chien

C. R. Cole

S. F. Conley

R. L. Dirkes

P. E. Dresel (5)

W. J. Deutsch

O. T. Farmer

M. J. Fayer

E. J. Freeman

M. D. Freshley

J. S. Fruchter (10)

G. W. Gee

D. R. Geist

R. E. Gephart

T. J Gilmore

S. M. Goodwin

R. W. Hanf

M. J. Hartman (15)

P. S. Henry

J. M. Keller

E. A. Lepel

S. P. Luttrell

M. D. Johnson
No. of

$\underline{\text { Copies }}$

K6-85

E6-35

K6-04

K6-96

K6-81

K9-36

K6-75

K6-75

K6-96

K6-81

P8-50

K9-33

K9-36

K9-33

K6-96

K9-33

K6-85

K9-88

K6-81

P7-07

K6-75

K6-96

K6-75

K9-36

P8-01

K6-96

K6-96
C. T. Kincaid

K9-33

C. K. Knudson

K6-04

G. V. Last

K6-81

T. L. Liikala

P. D. Meyer

T. G. Naymik

D. R. Newcomer

K. B. Olsen

B. E. Opitz

M. S. Peffers

R. E. Peterson

S. P. Reidel

J. T. Rieger

R. G. Riley

K. Rhoads

R. J. Serne

D. S. Sklarew

F. A. Spane, Jr.

P. D. Thorne

V. R. Vermeul

G. Whelan

B. A. Williams

M. D. Williams

S. K. Wurstner

J. M. Zachara

Hanford Technical Library (2)
K6-96

$\mathrm{BPO}$

K6-96

K6-96

K6-96

K6-75

BSRC

K6-96

K6-81

K6-96

K6-96

K3-54

K6-81

K6-96

K6-96

K9-33

K6-96

K9-36

K6-81

K9-36

K9-36

K8-96

P8-55 